\title{
Performance of Some Faba Bean Varieties in Relation to Phosphorus Fertilization and Some Microelements Spraying
}

Amany A. E. El-Safy; Salah A. H. Allam; El-Saeed M. M. El-Gedwy and Fadel T. Z. El-Sheikh Agronomy Department, Faculty of Agriculture, Benha University, Egypt

Corresponding author: alsaeed.algedwy@fagr.bu.edu.eg

\begin{abstract}
In order to study the effect of phosphorus fertilization rates and microelements spraying treatments on plant characteristics and yield traits as well as some seed chemical properties of faba bean varieties, an experiment was conducted in two successive growing seasons of 2018/2019 and 2019/2020 in the Farm of Agricultural Research and the Experimental Center of Faculty of Agriculture at Moshtohor, (Toukh Directorate, Kalyubia Governorate) Benha Univ. Egypt. The experimental design was split-split plot in RCBD in three replications. Phosphorus fertilizer was considered as the main plot in three rates $\left(0,15\right.$ and $30 \mathrm{~kg}_{2} \mathrm{O}_{5} /$ fed). Four microelements spraying treatments [Tap water (control), $\mathrm{Zn}, \mathrm{Mn}$ and mixed of $\mathrm{Zn}+\mathrm{Mn}$ ] were arranged in the sub plot. The sub-sub plots were occupied with three faba bean varieties (Giza 716, Nubaria 3 and Sakha 4). The obtained results could be outlined as following: Increasing phosphorus fertilizer rate from 0 to $30 \mathrm{~kg} \mathrm{P}_{2} \mathrm{O}_{5} / \mathrm{fed}$ induced significantly increased most vegetative growth, yield attributes, yield and seed chemical properties of faba bean under study except, mid physiological maturity, height to $1^{\text {st }}$ pod and phosphorus use efficiency were significantly decreased with rising phosphorus rates during the both seasons. The foliar spray by $\mathrm{Zn}$ and $\mathrm{Mn}$ as a single or in combination had significant effect on most faba bean traits under study compared with no microelements added during the both seasons. Faba bean plant treated with microelements foliar spray using $\mathrm{Zn}$ in combination with $\mathrm{Mn}$ was the most effective treatment for most faba bean characteristics in the both seasons. Mean performances of the investigated faba bean varieties for most faba bean traits under study were significant different during the both seasons. Faba bean variety Sakha 4 had higher values of chlorophyll content index at 85 DAS, plant height, height to $1^{\text {st }}$ pod, No. of branches/plant, plant weight, No. of pods/plant, No. of seeds/plant, seed yield/plant, biological yield/fed, seed yield/fed, straw yield/fed, phosphors use efficiency, seed $\mathrm{N}$ content and seed protein yield/fed in the both seasons. While, Nubaria 3 variety significantly gave the maximum mean values in mid physiological maturity, harvest index and 100-seed weight in the both seasons, respectively. The

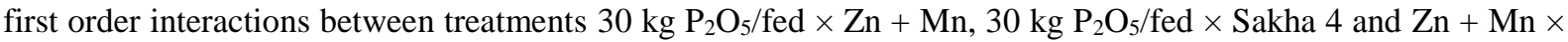
Sakha 4 as well as the second order interaction between treatments $30 \mathrm{~kg} \mathrm{P}_{2} \mathrm{O}_{5} / \mathrm{fed} \times \mathrm{Zn}+\mathrm{Mn} \times \mathrm{Sakha} 4$ were significantly recorded the maximum seed yield/plant, biological yield/fed, seed yield/fed and straw yield/fed in the both seasons. Therefore, this study recommends that Sakha 4 variety treated by $30 \mathrm{P}_{2} \mathrm{O}_{5} /$ fed and mixed spraying with $\mathrm{Zn} 0.3 \%+\mathrm{Mn} 0.3 \%$ in order to improve the production of faba bean under the condition of Toukh Directorate, Kalyubia Governorate, Egypt.
\end{abstract}

Keywords: Faba bean varieties, phosphorus fertilization, Zinc, Manganese.

\section{Introduction}

Faba bean (Vicia faba L.) is the most important legume crop for human and livestock in Egypt. It makes an important contribution to the diet of people in many countries. It represents a very interesting class of food crops due to its high protein content (30 $\%)$. It can grow successfully in different soil types and it increases soil fertility. World average cultivated area of faba bean reached 6136193 fed in 2019; the total production was 5431503 tonnes, with an average productivity of $885 \mathrm{~kg} / \mathrm{fed}$. In Egypt, Egyptian statistics indicates decreasing of faba bean cultivated area from 333757 fed in 2001 year to about 66248 fed in 2019, with decreasing percent of about $80.15 \%$ that lead to a decrease in faba bean production from 439480 tonnes in 2001 to about 95789 tonnes in 2019, with decreasing percent by about $78.20 \%$ in 2019 comparing with 2001 (http://www.fao.org/faostat).
Phosphorus is one of the major essential elements in plant life. These unique properties of phosphate produce water-stable anhydrides and esters that are important in energy storage and transfer in plant biochemical processes. Most notable are adenosine diphosphate and triphosphate (ADP and ATP). Energy is released when a terminal phosphate is split from ADP or ATP. The transfer of phosphate molecules to ATP from energy-transforming processes and from ATP to energy-requiring processes in the plants is known as phosphorylation. A portion of the energy derived from photosynthesis is conserved by phosphorylation of ADP to yield ATP in a process called photophosphorylation. Energy released during respiration is similarly harnessed in a process called oxidative phosphorylation. Beyond their role in energytransferring processes, phosphate bonds serve as important linkage groups. Phosphate is a structural component of phospholipids, nucleic acids, 
nucleotides, coenzymes, and phosphoproteins. Phospholipids are important in membrane structure. Nucleic acids of genes and chromosomes carry genetic material from cell to cell. As a monoester, phosphorus provides an essential ligand in enzymatic catalysis. Phytic acid, the hexaphosphate ester of myo-inositol phosphate, is the most common phosphorus reserve in seeds (Barker and Pilbeam, 2006 and Bakhsh et al. 2008).

Several investigations reported that increasing phosphorus rates caused significant increase in most vegetative growth, yield components, yield and seed chemical properties traits of faba bean except, No. of days from planting to $50 \%$ physiological maturity, height to $1^{\text {st }}$ pod and phosphorus use efficiency were significantly decreased (Weldua et al. 2012; Desta et al. 2015; Nebiyu et al. 2016; Abd AlKader et al. 2017; El-Agrodi et al. 2017; El-Sobky and Yasin 2017; Ghazi 2017; Kandil et al. 2019; Negasa et al. 2019 and Yasmin et al. 2020).

Microelements are required in small amounts and they affect directly or indirectly photosynthesis, vital processes in plants such as respiration, protein synthesis and reproduction phase (Kabata \& Pendias 1999 and Epstein \& Bloom 2005).

Zinc acts either as a metal component of enzymes or as a functional, structural, or regulatory cofactor of a large number of enzymes. More than 80 zinc containing proteins have been reported. The rate of protein synthesis and the protein content of zinc deficient plants are drastically reduced. The accumulation of amino acids and amides in these plants demonstrates the importance of zinc for protein synthesis. Zinc is an essential component of RNA polymerase and if the zinc is removed, the enzyme is inactivated. Zinc is also a constituent of ribosomes and is essential for their structural integrity (Epstein and Bloom, 2005).

Manganese serves as an activator for enzymes in growth processes. It assists iron in chlorophyll formation. It is part of the system where water is split and oxygen gas is liberated. The splitting of water is an oxidation, namely $2 \mathrm{H}_{2} \mathrm{O} \rightarrow \mathrm{O}_{2}+4 \mathrm{H}^{+}+4 \mathrm{e}^{-}$. The other protein in which manganese is an integral constituent is the manganese-containing superoxide dismutase. This enzyme is widespread in aerobic organisms. The function of this enzyme is to provide protection from free oxygen radicals formed when $\mathrm{O}_{2}$ receives a single electron. Superoxide dismutase's convert this highly toxic free radical into hydrogen peroxide $\left(\mathrm{H}_{2} \mathrm{O}_{2}\right)$ which is subsequently broken down to water (Epstein and Bloom, 2005).

Several investigators reported that significantly increases on most vegetative growth, yield components, yield and seed chemical analysis of faba bean by using microelements foliar spray of $\mathrm{Zn}$ and Mn singly or combined (Weldua et al. 2012; Mekkei 2014; Salem et al. 2014; Desta et al. 2015; Jarecki et al., 2016; El-Agrodi et al. 2017; El-Sobky and Yasin 2017; Ghazi 2017; Al-Selawy et al. 2018;
Mahdy and Ahmed 2018; El-Shafey et al. 2019; Al-Shumary 2020 and Nour El-Din et al. 2020).

Varietal differences among faba bean varieties have been reported by many investigators as Mekkei 2014; Salem et al. 2014; Jarecki et al., 2016; Nebiyu et al. 2016; Abd AlKader et al. 2017; AlSelawy et al. 2018; Mahdy and Ahmed 2018; ElShafey et al. 2019; Kandil et al. 2019; Negasa et al. 2019; Al-Shumary 2020 and Nour El-Din et al. 2020, they found that significant differences among the test varieties in most faba bean traits

The objectives of the present study are to investigate the effect of three rates of phosphorus fertilization and four treatments of microelements foliar spray and three faba bean varieties and their interactions on vegetative growth, yield components, yield and seed chemical properties of faba bean.

\section{Materials and Methods:}

A field experiment was carried out in the Farm of Agricultural Research and the Experimental Center of Faculty of Agriculture at Moshtohor, (Toukh Directorate, Kalyubia Governorate) Benha Univ. Egypt, during the two successive seasons of $2018 / 2019$ and 2019/2020. The objective of this investigation was to study the effect of some phosphorus fertilization rates and microelements spraying treatments on growth vegetative, yield components, yield as well as some seed chemical properties of three faba bean varieties.

The factors under study which arranged in splitsplit plot in randomized complete block design with three replications.

The main plots were assigned to three phosphorous fertilizer rates $(0,15$ and $30 \mathrm{~kg}$ $\left.\mathrm{P}_{2} \mathrm{O}_{5} / \mathrm{fed}\right)$. Phosphorus rates were added after ridging and before sowing in form of calcium super phosphate $\left(12.5 \% \mathrm{P}_{2} \mathrm{O}_{5}\right)$ in both growing seasons.

Four microelements spraying treatments [Tap water (control), Zn $0.6 \%$, Mn $0.6 \%$ and $\mathrm{Zn} 0.3 \%+$ $\mathrm{Mn} 0.3 \%]$ were arranged in the sub-plots. Microelements were repeated three times as foliar spray; the first at 40 days after sowing (DAS) and repeated with 15 days intervals during both seasons in form of Zinc Sulphate ( $\left.\mathrm{Zn} \mathrm{So} \mathrm{So}_{4} 7 \mathrm{H}_{2} \mathrm{O}\right)$ and Manganese Sulphate (Mn $\left.\mathrm{So}_{4} . \quad \mathrm{H}_{2} \mathrm{O}\right)$ for microelements under study using Gelatine Powder as a wetting agent to be sure that the solution mostly covered the green parts, the spray solution volume was $400 \mathrm{~L} /$ fed using a hand operated compressed air. The application was carried out between 02:00 and 04:00 p.m.

The sub-sub plots were occupied with three faba bean varieties i.e., Giza 716, Nubaria 3 and Sakha 4. The variety seeds were obtained from Food Legumes Research Section, Field Crops Research Institute, Agricultural Research Center, Egypt. 
Soil samples were taken before faba bean sowing to depth of $0-30 \mathrm{~cm}$ for chemical and mechanical analysis of the experimental soil were determined according to the methods of Association of Official Analytical Chemists described in (A.O.A.C., 2005) and represented in Table 1 in each of two growing seasons. Soil texture of the experimental site was clay texture with $\mathrm{pH}$ nearly of 8.0.

Table 1. Chemical and mechanical properties of the experimental soil during the 2018/2019 and 2019/2020 seasons.

\begin{tabular}{|c|c|c|}
\hline \multirow{2}{*}{ Properties } & \multicolumn{2}{|c|}{ Season } \\
\hline & 2018/2019 & $2019 / 2020$ \\
\hline \multicolumn{3}{|l|}{ Chemical analysis } \\
\hline E.C. & 2.26 & 2.32 \\
\hline $\mathrm{pH}(1: 2.5)$ & 7.97 & 7.95 \\
\hline $\mathrm{CaCo}_{3} \%$ & 2.96 & 2.90 \\
\hline O.M \% & 2.23 & 2.46 \\
\hline $\mathrm{N} \%($ total $)$ & 0.210 & 0.223 \\
\hline $\mathrm{N}(\mathrm{mg} / \mathrm{kg})($ Exchangeable) & 70.31 & 75.15 \\
\hline $\mathrm{P} \%($ total $)$ & 0.130 & 0.159 \\
\hline $\mathrm{P}(\mathrm{mg} / \mathrm{kg})$ (Exchangeable) & 23.49 & 27.16 \\
\hline $\mathrm{K} \%($ total $)$ & 0.62 & 0.63 \\
\hline $\mathrm{K}(\mathrm{mg} / \mathrm{kg})($ Exchangeable $)$ & 916.46 & 943.68 \\
\hline \multicolumn{3}{|c|}{ Soluble cations and anions (mg/kg) } \\
\hline $\mathrm{Mn}^{++}$ & 7.9 & 9.3 \\
\hline $\mathrm{Fe}^{++}$ & 10.5 & 8.8 \\
\hline $\mathrm{Zn}^{++}$ & 2.3 & 2.4 \\
\hline $\mathrm{Ca}^{++}$ & 182.4 & 187.4 \\
\hline $\mathrm{Mg}^{++}$ & 48.60 & 50.58 \\
\hline $\mathrm{K}^{+}$ & 46.80 & 52.26 \\
\hline $\mathrm{Na}^{+}$ & 201.94 & 204.24 \\
\hline $\mathrm{Cl}^{-}$ & 231.82 & 261.64 \\
\hline $\mathrm{Co}_{3}^{--}$ & 0.00 & 0.00 \\
\hline $\mathrm{H} \mathrm{Co}_{3}^{-}$ & 357.46 & 378.20 \\
\hline $\mathrm{So} 4^{--}$ & 516.48 & 490.08 \\
\hline \multicolumn{3}{|c|}{ Particle size distribution (mechanical analysis) } \\
\hline Course sand $\%$ & 7.31 & 5.43 \\
\hline Find sand $\%$ & 27.75 & 24.33 \\
\hline Silt \% & 14.41 & 13.52 \\
\hline Clay \% & 50.53 & 56.72 \\
\hline Texture grade & Clay & Clay \\
\hline
\end{tabular}

The preceding summer crop in the both seasons was maize (Zea mays L.). The sub-sub plot area was $10.8 \mathrm{~m}^{2}$ and contained five ridges of $3.6 \mathrm{~m}$ long and $60 \mathrm{~cm}$ apart. Faba bean seeds were planted on $6^{\text {th }}$ November in the first season 2018/2019 and $29^{\text {th }}$ October in second season 2019/2020. Faba bean planting was done by the local method of dibbling 2 to 4 seeds in each hill by hand with distance between hills was $15 \mathrm{~cm}$ apart and after 35 days of sowing thinning was carried out in order to maintain better two seedlings/hill (93333 plants/fed). Nitrogen fertilizer was applied in form of urea $(46 \% \mathrm{~N})$, according to the recommended rate $20 \mathrm{~kg} \mathrm{~N} / \mathrm{fed}$ at one dose before the first irrigation in each season. The normal cultural practices for growing faba bean plants were done as recommended.

\section{Characters studied:}

1- Chlorophyll content index (CCI) at 85 days after sowing, three plants in three different ridges were randomly selected, and chlorophyll content index (CCI) of upper, middle and lower leaves was measured by a Minolta Chlorophyll Meter SPAD-502 (MINOLTA CO., LTD. JAPAN).

2- Number of days to $50 \%$ physiological maturity (days).

At harvest, random sample of ten guarded plants from each sub-sub plots in the both seasons was taken to determine the following measurements:

3- Plant height $(\mathrm{cm})$.

4- Height to first pod $(\mathrm{cm})$.

5- Number of branches/plant on the main stem.

6- Plant weight (g).

7- Number of pods/plant.

8- Number of seed plant.

9- Seed yield/plant (g).

10- Harvest index (\%), it was calculated by using the following formula:

Harvest index $(\%)=($ Seed yield/plant $/$ plant weight $) \times 100$.

The whole faba bean plants of three middle ridges of each sub-sub plots have been used for estimating of

11- Weight of 100-seed (g).

12- Biological yield/fed (kg).

13- Seed yield/fed $(\mathrm{kg})$, it was calculated by using the following formula:

Seed yield/fed $=($ biological yield/fed $\times$ harvest index $) / 100$.

14- Straw yield/fed $(\mathrm{kg})$, it was calculated by using the following formula:

Straw yield/fed = biological yield/fed - seed yield/fed.

15- Phosphorus use efficiency (kg grain $/ \mathrm{kg} \quad \mathrm{P}_{2} \mathrm{O}_{5}$ applied) was calculated according to Fageria and Barbosa (2007) as follows:

PUE $=\frac{\text { Seed yield of treatment }(\mathrm{kg} / \mathrm{fed})-\text { Seed yield of control }(\mathrm{kg} / \mathrm{fed})}{\text { Phosphorus applied }(\mathrm{kg} / \mathrm{fed})}$

Seeds samples were taken after harvest at random from each seeds of ten plants to determine some seed chimerical properties in Agricultural Analyses and Consultations Center (Project No. CP4-092-BEN) of Faculty of Agriculture at Moshtohor, Benha university, Egypt to estimate:

16- Seed nitrogen content according to the modified micro Kjeldahl method was determined according to the methods of Association of Official Analytical Chemists described in (A. O. A. C., 2005).

17- Seed protein yield/fed $(\mathrm{kg})$, it was calculated by using the following formula

Seed protein yield/fed $=($ seed yield $/ \mathrm{fed} \times$ seed $\mathrm{N}$ content $\times 6.25) / 100$.

18- Seed $P$ content.

19- Seed $\mathrm{Zn}$ content $(\mathrm{mg} / \mathrm{kg})$. 
20- Seed Mn content ( $\mathrm{mg} / \mathrm{kg})$.

Phosphorus was determined colorimetrically was measured by flame-photometer. However, $\mathrm{Zn}$ and Mn determined by Atomic Absorption Spectrophotometer (Perkin-Elmer 2380) according to the methods described in (A. O. A. C., 2005).

\section{Statistical analysis:}

The analysis of variance was carried out according to the procedure described by Gomez and Gomez (1984). Data were statistically analyzed according to using the MSTAT-C Statistical Software Package (Freed, 1991). Where the F-test showed significant differences among means L. S. D. test at 0.05 level was used to compare between means.

\section{Results and Discussion:}

\section{1- Effect of phosphorus fertilization rates:}

Results in Tables 2, 3, 4 and 5 indicated that increasing phosphorus fertilization rates from 0 up to $30 \mathrm{~kg} \mathrm{P}_{2} \mathrm{O}_{5} /$ fed caused significant increments in most vegetative growth, yield attributes, yield and seed chemical properties of faba bean under study except, No. of days from planting to $50 \%$ physiological maturity, height to $1^{\text {st }}$ pod and phosphorus use efficiency were significantly decreased with rising phosphorus fertilization rates during 2018/2019 and 2019/2020 seasons. Meanwhile, seed N content, seed $\mathrm{Zn}$ content and seed Mn content were not significantly affected in the both seasons. But, the differences between phosphorus fertilization rates at 15 and $30 \mathrm{~kg} \mathrm{P}_{2} \mathrm{O}_{5} /$ fed on mid physiological maturity, plant height, No. of branches/plant, No. of pods/plant and 100-seed weight in the both seasons as well as biological yield/fed, seed yield/fed and straw yield/fed in the first season in addition to seed $\mathrm{P}$ content in second season were not significant.

Faba bean plants treated with $30 \mathrm{~kg} \mathrm{P}_{2} \mathrm{O}_{5} / \mathrm{fed}$ recorded significantly the maximum chlorophyll content index at 85 DAS (35.84 and 40.56), plant height $(91.15$ and $105.68 \mathrm{~cm})$, No. of branches/plant (3.170 and 4.149), plant weight (48.61 and $94.62 \mathrm{~g}$ ), No. of pods/plant (7.885 and 13.183), No. of seeds/plant (26.08 and 47.04), seed yield/plant (20.43 and $41.77 \mathrm{~g}$ ), harvest index (41.58 and $43.89 \%$ ), 100 -seed weight (77.90 and $88.54 \mathrm{~g})$, biological yield/fed (2100.3 and $3532.1 \mathrm{~kg}$ ), seed yield/fed (881.8 and $1565.3 \mathrm{~kg})$, straw yield/fed (1218.6 and $1966.8 \mathrm{~kg})$, seed protein yield/fed (198.63 and 367.27 $\mathrm{kg})$ and seed P content $(0.607$ and $0.624 \%)$ as well as recorded significantly the shortest period from planting to $50 \%$ physiological maturity (132.14 and 134.33 days) as well as gave lower position of the $1^{\text {st }}$ pod $(17.09$ and $21.05 \mathrm{~cm})$ in the both seasons, respectively.

The superiority rations in the first season between $30 \mathrm{~kg} \mathrm{P}_{2} \mathrm{O}_{5} /$ fed and each of 0 and $15 \mathrm{~kg} \mathrm{P}_{2} \mathrm{O}_{5} /$ fed were 4.00 and $16.63 \%$ for chlorophyll content index; 12.05 and $108.28 \%$ for No. of branches/plant; 16.01 and $78.58 \%$ for plant weight; 11.28 and $70.56 \%$ for No. of pods/plant; 15.14 and $78.14 \%$ for No. of seeds/plant; 6.99 and $40.85 \%$ for biological yield/fed; 9.12 and $52.85 \%$ for seed yield/fed; 5.52 and $33.27 \%$ for straw yield/fed; 11.47 and $70.05 \%$ for seed protein yield/fed in addition to 6.68 and $58.90 \%$ for seed $\mathrm{P}$ content, respectively. The increases rations in the second season when faba bean treated with $30 \mathrm{~kg} \mathrm{P}_{2} \mathrm{O}_{5} /$ fed over each of 0 and $15 \mathrm{~kg} \mathrm{P}_{2} \mathrm{O}_{5} /$ fed were 6.07 and $20.32 \%$ for chlorophyll content index; 13.06 and $90.63 \%$ for No. of branches/plant; 11.66 and $61.80 \%$ for plant weight; 9.68 and $56.09 \%$ for No. of pods/plant; 11.92 and $62.99 \%$ for No. of seeds/plant; 8.23 and $40.47 \%$ for biological yield/fed; 10.49 and $54.95 \%$ for seed yield/fed; 6.50 and $30.75 \%$ for straw yield/fed; 14.11 and $71.78 \%$ for seed protein yield/fed in addition to 1.46 and $34.19 \%$ for seed $\mathrm{P}$ content, respectively. The maximum phosphorus use efficiency was recorded from faba bean treated with $15 \mathrm{~kg} \mathrm{P}_{2} \mathrm{O}_{5} /$ fed being 15.42 and $27.10 \mathrm{~kg}$ seed $/ \mathrm{kg}$ $\mathrm{P}_{2} \mathrm{O}_{5}$ applied in the both seasons respectively.

Such results stated the vital role of phosphorus fertilization in improving the productivity of faba bean. The superiority of phosphorus application as 30 $\mathrm{kg}_{2} \mathrm{O}_{5} /$ fed on seed yield/fed may be due to its good effect on chlorophyll content index, plant height, No. of branches/plant, plant weight, No. of pods/plant, No. of seeds/plant, seed yield/plant, harvest index, 100 -seed weight and biological yield/fed as well as recorded lower position of the $1^{\text {st }}$ pod during the both seasons. These results are in harmony with those obtained by Weldua et al. 2012; Desta et al. 2015; Nebiyu et al. 2016; Abd AlKader et al. 2017; ElAgrodi et al. 2017; El-Sobky and Yasin 2017; Ghazi 2017; Kandil et al. 2019; Negasa et al. 2019 and Yasmin et al. 2020.

\section{2- Effect of foliar spray by microelements treatments:}

Results presented in Tables 2, 3, 4 and 5 indicated that most vegetative growth, yield components, yield and seed chemical analysis of faba bean in the both seasons were significant increased by microelements foliar spray using $\mathrm{Zn}$ and $\mathrm{Mn}$ singly or combined over the control treatment (Tap water) except, height to $1^{\text {st }}$ pod was significantly decreased in 2018/2019 and 2019/2020 seasons. Meanwhile, No. of branches/plant, seed N content and seed $\mathrm{P}$ content were not significant. But, the differences between foliar spray by singly $\mathrm{Zn}$ and $\mathrm{Zn}$ in combination with $\mathrm{Mn}$ on most traits were not significant in the both seasons.

Faba bean plants treated with microelements foliar spray using $\mathrm{Zn}+\mathrm{Mn}$ was the most effective treatment and significantly produced the maximum plant height $(92.42$ and $108.54 \mathrm{~cm})$, plant weight (46.21 and $89.49 \mathrm{~g})$, No. of pods/plant $(7.518$ and 12.619), No. of seeds/plant (24.70 and 44.78), seed yield/plant (19.52 and $39.71 \mathrm{~g})$, harvest index (41.64 
and $43.85 \%)$, 100-seed weight (77.95 and $87.96 \mathrm{~g})$, biological yield/fed (2134.2 and $3521.3 \mathrm{~kg})$, seed yield/fed (897.9 and $1561.1 \mathrm{~kg})$, straw yield/fed (1236.3 and $1960.2 \mathrm{~kg}$ ), phosphors use efficiency (14.75 and $27.13 \mathrm{~kg}$ seed $/ \mathrm{kg} \mathrm{P}_{2} \mathrm{O}_{5}$ applied) and seed protein yield/fed (196.98 and $355.38 \mathrm{~kg}$ ) as well as gave significantly lower position of the $1^{\text {st }}$ pod (17.90 and $21.46 \mathrm{~cm}$ ) in the both seasons, respectively. Meanwhile, faba bean plants treated with foliar spray by singly $\mathrm{Zn}$ recorded the longest period from planting to mid physiological maturity (135.11 and 138.33 days) in addition to recorded the highest seed $\mathrm{Zn}$ content $(113.02$ and $122.31 \mathrm{mg} / \mathrm{kg})$ in the both seasons, respectively.

The maximum chlorophyll content index at 85 DAS (35.74 and 39.73) and seed Mn content (35.10 and $41.06 \mathrm{mg} / \mathrm{kg}$ ) in the both seasons, respectively were obtained from faba bean plants treated with foliar spray by singly Mn.

In the first season the superiority rations when using microelements foliar spray of $\mathrm{Mn}, \mathrm{Zn}$ or $\mathrm{Zn}+$ Mn over the control treatment (tap water) were 13.64, 5.25 and $9.44 \%$ for chlorophyll content index; 35.52 , 49.10 and $60.45 \%$ for plant weight; $35.33,45.73$ and $53.96 \%$ for No. of pods/plant; 36.34, 48.97 and $59.15 \%$ for No. of seeds/plant; 34.10, 46.87 and $54.23 \%$ for biological yield/fed; 41.20, 57.22 and $68.40 \%$ for seed yield/fed; $29.63,40.37$ and $45.33 \%$ for straw yield/fed; $14.90,32.95$ and $40.88 \%$ for phosphorus use efficiency; 47.34, 70.11 and $78.29 \%$ for seed protein yield/fed; 4.72, 21.71 and $12.04 \%$ for seed $\mathrm{Zn}$ content in addition to $73.68,14.65$ and $40.28 \%$ for seed Mn content, respectively. The increases rations in the second season when faba bean treated with $\mathrm{Mn}, \mathrm{Zn}$ or $\mathrm{Zn}+\mathrm{Mn}$ over the control were $13.35,5.65$ and $8.96 \%$ for chlorophyll content index; 17.44, 27.55 and $35.63 \%$ for plant weight; 21.21, 31.09 and $37.87 \%$ for No. of pods/plant; 22.05, 33.24 and $41.48 \%$ for No. of seeds/plant; 27.89, 38.45 and $45.07 \%$ for biological yield/fed; 38.46, 52.94 and $62.43 \%$ for seed yield/fed; 20.96, 28.95 and $33.69 \%$ for straw yield/fed; 60.08, 79.42 and $86.08 \%$ for phosphorus use efficiency; 42.35, 63.35 and $69.92 \%$ for seed protein yield/fed; $4.11,19.88$ and $12.11 \%$ for seed $\mathrm{Zn}$ content in addition to 59.46, 13.59 and $33.09 \%$ for seed Mn content, respectively.

The increase in vegetative, yield components, yield and seed chemical properties of faba bean with the application of microelements especially $\mathrm{Zn}+\mathrm{Mn}$ treatment may be due to the synergetic role of microelements in improving directly or indirectly photosynthesis, vital processes in plant such as respiration, protein synthesis, reproduction phase, biochemical and physiological activities.

The superiority of microelements application as mixed $\mathrm{Zn}+\mathrm{Mn}$ on seed yield/fed may be due to its good effect on plant height, plant weight, No. of pods/plant, No. of seeds/plant, seed yield/plant, harvest index, 100-seed weight and biological yield/fed in addition to lower position of the $1^{\text {st }}$ pod.

Many investigators came out with similar results as Mekkei 2014; Jarecki et al., 2016; El-Sobky and Yasin 2017; Al-Selawy et al. 2018; Mahdy and Ahmed 2018; El-Shafey et al. 2019; Al-Shumary 2020 and Nour El-Din et al. 2020 who found that foliar spray with mixed between $\mathrm{Zn}$ and $\mathrm{Mn}$ gave the best traits of faba bean.

\section{3- Faba bean varieties performance:}

Mean performances of the investigated faba bean varieties (Giza 716, Nubaria 3 and Sakha 4) for most vegetative growth, yield components, yield and seed chemical analysis of faba bean under study were significant affected except, seed P content, seed Zn content and seed Mn content during 2018/2019 and 2019/2020 seasons as shown in Tables 2, 3, 4 and 5. The differences in mid physiological maturity between Sakha 4 and Giza 716 as well as among Nubaria 3 and Giza 716 on phosphorus use efficiency did not reach the level of significance only in the first season.

Results may reveal the superiority of Sakha 4 variety in chlorophyll content index at 85 DAS (37.23 and 41.20), plant height (100.38 and 111.53 $\mathrm{cm})$, height to $1^{\text {st }}$ pod $(23.42$ and $27.40 \mathrm{~cm})$, No. of branches/plant (2.993 and 3.839), plant weight (51.84 and $97.93 \mathrm{~g}$ ), No. of pods/plant (8.168 and 13.338), No. of seeds/plant (28.33 and 49.63), seed yield/plant (21.26 and $41.93 \mathrm{~g})$, biological yield/fed (2396.7 and $3901.5 \mathrm{~kg}$ ), seed yield/fed (979.1 and $1671.3 \mathrm{~kg}$ ), straw yield/fed (1417.6 and $2230.2 \mathrm{~kg}$ ), phosphors use efficiency (14.40 and $30.42 \mathrm{~kg}$ seed/kg $\mathrm{P}_{2} \mathrm{O}_{5}$ applied), seed $\mathrm{N}$ content (3.612 and $3.798 \%$ ) and seed protein yield/fed $(223.32$ and $401.30 \mathrm{~kg})$ in the both seasons, respectively.

In the first season the superiority ratios between faba bean variety of Sakha 4 over each of Giza 716 and Nubaria 3 were 25.14 and $9.31 \%$ for chlorophyll content index; 28.82 and $15.55 \%$ for plant height; 37.36 and $10.84 \%$ for height to $1^{\text {st }}$ pod; 53.09 and $16.32 \%$ for No. of branches/plant; 38.20 and 82.66 $\%$ for plant weight; 23.89 and $69.00 \%$ for No. of pods/plant; 45.73 and $81.49 \%$ for No. of seeds/plant; 34.41 and $74.32 \%$ for biological yield/fed; 28.47 and $86.32 \%$ for seed yield/fed; 38.86 and $66.89 \%$ for straw yield/fed in addition to 45.06 and $91.92 \%$ for seed protein yield/fed, respectively. The excess ratios in the second season when faba bean planting variety of Nubaria 3 over each of Giza 716 and Sakha 4 were 20.68 and $10.87 \%$ for chlorophyll content index; 16.61 and $10.64 \%$ for plant height; 38.95 and $7.75 \%$ for height to $1^{\text {st }}$ pod; 40.21 and $13.92 \%$ for No. of branches/plant; 27.65 and $54.98 \%$ for plant weight; 16.94 and $49.78 \%$ for No. of pods/plant; 33.95 and $58.82 \%$ for No. of seeds/plant; 27.10 and $66.82 \%$ for biological yield/fed; 20.72 and $78.50 \%$ for seed yield/fed; 32.34 and $59.02 \%$ for straw yield/fed in addition to 40.64 and $85.55 \%$ for seed protein yield/fed, respectively. 
Table 2. Mean values of chlorophyll content index at 85 DAS, days to $50 \%$ physiological maturity, plant height, height to $1^{\text {st }}$ pod and No. of branches/plant as affected by phosphorus fertilization rates, foliar spray by some microelements and varieties of faba bean during 2018/2019 (1 $\left.1^{\text {st }}\right)$ and 2019/2020 (2 $\left.2^{\text {nd }}\right)$ seasons.

\begin{tabular}{|c|c|c|c|c|c|c|c|c|c|c|c|}
\hline \multirow[t]{2}{*}{ Treatment } & \multirow{2}{*}{$\begin{array}{c}\text { Trait } \\
\text { Season }\end{array}$} & \multicolumn{2}{|c|}{$\begin{array}{c}\text { Chlorophyll } \\
\text { content index at } \\
85 \text { DAS } \\
\end{array}$} & \multicolumn{2}{|c|}{$\begin{array}{c}\text { Days to } 50 \% \\
\text { physiological } \\
\text { maturity (days) }\end{array}$} & \multicolumn{2}{|c|}{ Plant height (cm) } & \multicolumn{2}{|c|}{$\begin{array}{l}\text { Height to } 1^{\text {st }} \text { pod } \\
(\mathbf{c m})\end{array}$} & \multicolumn{2}{|c|}{$\begin{array}{c}\text { No. of } \\
\text { branches/plant }\end{array}$} \\
\hline & & $1^{\text {st }}$ & $2^{\text {nd }}$ & $\mathbf{1}^{\text {st }}$ & $2^{\text {nd }}$ & $\mathbf{1}^{\text {st }}$ & $2^{\text {nd }}$ & $1^{\text {st }}$ & $2^{\text {nd }}$ & $1^{\text {st }}$ & $2^{\text {nd }}$ \\
\hline \multicolumn{12}{|c|}{ Phosphorus fertilization rates (P) } \\
\hline \multicolumn{2}{|c|}{$\mathbf{0}$} & 30.73 & 33.71 & 135.45 & 139.78 & 84.60 & 98.36 & 25.46 & 27.85 & 1.522 & 2.166 \\
\hline \multicolumn{2}{|c|}{$15 \mathrm{~kg} \mathrm{P}_{2} \mathrm{O}_{5} / \mathrm{fed}$} & 34.46 & 38.24 & 133.53 & 136.31 & 89.41 & 103.93 & 19.07 & 23.65 & 2.829 & 3.652 \\
\hline \multicolumn{2}{|c|}{$30 \mathrm{~kg} \mathrm{P}_{2} \mathrm{O}_{5} / \mathrm{fed}$} & 35.84 & 40.56 & 132.14 & 134.33 & 91.15 & 105.68 & 17.09 & 21.05 & 3.170 & 4.129 \\
\hline \multicolumn{2}{|c|}{ L.S.D at $5 \%$} & 1.05 & 1.32 & 1.81 & 2.25 & 2.87 & 3.52 & 1.45 & 1.53 & 0.536 & 0.623 \\
\hline \multicolumn{12}{|c|}{ Microelements (M) } \\
\hline \multicolumn{2}{|c|}{ Control (Tap water) } & 31.45 & 35.05 & 131.89 & 134.41 & 83.03 & 96.59 & 23.52 & 27.33 & 2.403 & 3.180 \\
\hline \multicolumn{2}{|c|}{$\mathbf{Z n}$} & 33.10 & 37.03 & 135.11 & 138.33 & 90.20 & 104.91 & 19.54 & 23.30 & 2.541 & 3.364 \\
\hline \multicolumn{2}{|l|}{ Mn } & 35.74 & 39.73 & 133.52 & 136.92 & 87.90 & 100.60 & 21.18 & & 2.496 & 3.279 \\
\hline \multicolumn{2}{|l|}{$\mathbf{Z n}+\mathbf{M n}$} & 34.42 & 38.19 & 134.30 & 137.56 & 92.42 & 108.54 & 17.90 & 21.46 & 2.588 & 3.439 \\
\hline \multicolumn{2}{|l|}{ L.S.D at $5 \%$} & 0.87 & 0.96 & 1.61 & 1.75 & 2.11 & 2.35 & 1.25 & 1.29 & N.S. & N.S. \\
\hline \multicolumn{12}{|c|}{ Faba bean varieties $(V)$} \\
\hline \multicolumn{2}{|l|}{ Giza 716} & 34.06 & 37.16 & 132.31 & 134.56 & 86.87 & 100.80 & 21.13 & 25.43 & 2.573 & 3.370 \\
\hline \multicolumn{2}{|l|}{ Nubaria 3} & 29.75 & 34.14 & 135.31 & 139.14 & 77.92 & 95.64 & 17.05 & 19.72 & 1.955 & 2.738 \\
\hline \multicolumn{2}{|l|}{ Sakha 4} & 37.23 & 41.20 & 133.50 & 136.72 & 100.38 & 111.53 & 23.42 & 27.40 & 2.993 & 3.839 \\
\hline \multicolumn{2}{|l|}{ L.S.D at $5 \%$} & 0.65 & 0.89 & 1.21 & 1.36 & 1.98 & 2.15 & 1.02 & 1.11 & 0.315 & 0.383 \\
\hline \multirow{4}{*}{$\begin{array}{l}\text { F test } \\
\text { Prob. }\end{array}$} & $\mathbf{P} \times \mathbf{M}$ & $* *$ & $* *$ & $* *$ & $* *$ & $* *$ & $* *$ & $* *$ & $* *$ & N.S. & N.S. \\
\hline & $\mathbf{P} \times \mathbf{V}$ & $* *$ & $* *$ & N.S. & N.S. & $* *$ & $* *$ & $* *$ & $* *$ & $* *$ & $* *$ \\
\hline & $\mathbf{M} \times \mathbf{V}$ & $* *$ & $* *$ & N.S. & N.S. & $* *$ & $* *$ & N.S. & N.S. & N.S. & N.S. \\
\hline & $\times \mathbf{M} \times \mathbf{V}$ & $* *$ & $* *$ & N.S. & N.S. & N.S. & N.S. & N.S. & N.S. & N.S. & N.S. \\
\hline
\end{tabular}

** Significant and N.S. No significant

Table 3. Mean values of plant weight, No. of pods/plant, No. of seeds/plant, seed yield/plant and harvest index as affected by phosphorus fertilization rates, foliar spray by some microelements and varieties of faba bean during 2018/2019 $\left(1^{\text {st }}\right)$ and 2019/2020 (2 $\left.{ }^{\text {nd }}\right)$ seasons.

\begin{tabular}{|c|c|c|c|c|c|c|c|c|c|c|c|}
\hline \multirow{2}{*}{ Treatment } & \multirow{2}{*}{$\frac{\text { Trait }}{\text { Season }}$} & \multicolumn{2}{|c|}{ Plant weight (g) } & \multicolumn{2}{|c|}{ No. of pods/plant } & \multicolumn{2}{|c|}{ No. of seeds/plant } & \multicolumn{2}{|c|}{$\begin{array}{c}\text { Seed yield/plant } \\
(\mathrm{g})\end{array}$} & \multicolumn{2}{|c|}{$\begin{array}{c}\text { Harvest index } \\
(\%)\end{array}$} \\
\hline & & $1^{\text {st }}$ & $2^{\text {nd }}$ & $1^{\text {st }}$ & $2^{\text {nd }}$ & $1^{\text {st }}$ & $2^{\text {nd }}$ & $\mathbf{1}^{\text {st }}$ & $2^{\text {nd }}$ & $\mathbf{1}^{\text {st }}$ & $2^{\text {nd }}$ \\
\hline \multicolumn{12}{|c|}{ Phosphorus fertilization rates (P) } \\
\hline 0 & & 27.22 & 58.48 & 4.623 & 8.446 & 14.64 & 28.86 & 10.53 & 23.52 & 38.21 & 39.77 \\
\hline 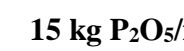 & fed & 41.90 & 84.74 & 7.086 & 12.020 & 22.65 & 42.03 & 17.27 & 36.67 & 40.78 & 42.92 \\
\hline $30 \mathrm{~kg} \mathrm{P}_{2} \mathrm{O}_{5} /$ & fed & 48.61 & 94.62 & 7.885 & 13.183 & 26.08 & 47.04 & 20.43 & 41.77 & 41.58 & 43.89 \\
\hline L.S.D at $5 \%$ & & 5.32 & 7.65 & 1.575 & 1.636 & 2.98 & 3.25 & 2.57 & 2.98 & 0.69 & 0.73 \\
\hline \multicolumn{12}{|c|}{ Microelements (M) } \\
\hline Control ( $\mathrm{Ta}$ & p water) & 28.80 & 65.98 & 4.883 & 9.153 & 15.52 & 31.65 & 11.12 & 26.20 & 38.14 & 39.22 \\
\hline Zn & & 42.94 & 84.16 & 7.116 & 11.999 & 23.12 & 42.17 & 17.78 & 36.82 & 40.85 & 43.26 \\
\hline Mn & & 39.03 & 77.49 & 6.608 & 11.094 & 21.16 & 38.63 & 15.89 & 33.21 & 40.13 & 42.45 \\
\hline $\mathbf{Z n}+\mathbf{M n}$ & & 46.21 & 89.49 & 7.518 & 12.619 & 24.70 & 44.78 & 19.52 & 39.71 & 41.64 & 43.85 \\
\hline L.S.D at $5 \%$ & & 4.62 & 5.88 & 1.354 & 1.621 & 2.53 & 3.16 & 2.38 & 2.72 & 0.63 & 0.72 \\
\hline \multicolumn{12}{|c|}{ Faba bean varieties (V) } \\
\hline Giza 716 & & 28.38 & 63.19 & 4.833 & 8.905 & 15.61 & 31.25 & 10.88 & 25.41 & 37.78 & 39.65 \\
\hline Nubaria 3 & & 37.51 & 76.72 & 6.593 & 11.406 & 19.44 & 37.05 & 16.10 & 34.62 & 42.29 & 44.50 \\
\hline Sakha 4 & & 51.84 & 97.93 & 8.168 & 13.338 & 28.33 & 49.63 & 21.26 & 41.93 & 40.51 & 42.43 \\
\hline \multirow[t]{2}{*}{ L.S.D at $5 \%$} & & 4.21 & 4.98 & 1.258 & 1.435 & 2.44 & 2.84 & 2.19 & 2.48 & 0.61 & 0.69 \\
\hline & $\mathbf{P} \times \mathbf{M}$ & $* *$ & $* *$ & N.S. & N.S. & $* *$ & $* *$ & $* *$ & $* *$ & $* *$ & $* *$ \\
\hline \multirow{3}{*}{$\begin{array}{l}\text { F test } \\
\text { Prob. }\end{array}$} & $\mathbf{P} \times \mathbf{V}$ & $* *$ & $* *$ & $* *$ & $* *$ & $* *$ & $* *$ & $* *$ & $* *$ & $* *$ & $* *$ \\
\hline & $\mathbf{M} \times \mathbf{V}$ & $* *$ & $* *$ & N.S. & N.S. & $* *$ & $* *$ & $* *$ & $* *$ & N.S. & N.S. \\
\hline & $\times \mathbf{M} \times \mathbf{V}$ & N.S. & N.S. & N.S. & N.S. & $* *$ & $* *$ & $* *$ & $* *$ & N.S. & N.S. \\
\hline
\end{tabular}


Table 4. Mean values of 100-seed weight, biological yield/fed, seed yield/fed, straw yield/fed and phosphorus use efficiency as affected by phosphorus fertilization rates, foliar spray by some microelements and varieties of faba bean during 2018/2019 $\left(1^{\text {st }}\right)$ and 2019/2020 $\left(2^{\text {nd }}\right)$ seasons.

\begin{tabular}{|c|c|c|c|c|c|c|c|c|c|c|c|}
\hline \multirow[t]{2}{*}{ Treatment } & \multirow{2}{*}{$\begin{array}{c}\text { Trait } \\
\text { Season } \\
\end{array}$} & \multicolumn{2}{|c|}{$\begin{array}{l}\text { 100-seed weight } \\
\text { (g) }\end{array}$} & \multicolumn{2}{|c|}{$\begin{array}{c}\text { Biological yield } \\
(\mathrm{kg} / \mathrm{fed})\end{array}$} & \multicolumn{2}{|c|}{$\begin{array}{c}\text { Seed yield } \\
(\mathrm{kg} / \mathrm{fed})\end{array}$} & \multicolumn{2}{|c|}{$\begin{array}{c}\text { Straw yield } \\
(\mathrm{kg} / \mathrm{fed})\end{array}$} & \multicolumn{2}{|c|}{$\begin{array}{c}\text { Phosphorus use } \\
\text { efficiency }\end{array}$} \\
\hline & & $\mathbf{1}^{\text {st }}$ & $2^{\text {nd }}$ & $1^{\text {st }}$ & $2^{\text {nd }}$ & $1^{\text {st }}$ & $2^{\text {nd }}$ & $1^{\text {st }}$ & $2^{\text {nd }}$ & $1^{\text {st }}$ & $2^{\text {nd }}$ \\
\hline \multicolumn{12}{|c|}{ Phosphorus fertilization rates (P) } \\
\hline \multicolumn{2}{|l|}{$\mathbf{0}$} & 70.83 & 81.20 & 1491.2 & 2514.4 & 576.9 & 1010.2 & 914.4 & 1504.2 & -- & -- \\
\hline \multicolumn{2}{|c|}{ 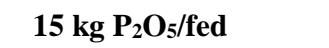 } & 75.46 & 86.84 & 1963.0 & 3263.5 & 808.1 & 1416.7 & 1154.9 & 1846.8 & 15.42 & 27.10 \\
\hline \multicolumn{2}{|c|}{$30 \mathrm{~kg} \mathrm{P}_{2} \mathrm{O}_{5} / \mathrm{fed}$} & 77.90 & 88.54 & 2100.3 & 3532.1 & 881.8 & 1565.3 & 1218.6 & 1966.8 & 10.16 & 18.50 \\
\hline \multicolumn{2}{|c|}{ L.S.D at $5 \%$} & 3.11 & 3.56 & 156.8 & 176.5 & 84.6 & 95.7 & 91.5 & 103.4 & 2.23 & 2.57 \\
\hline \multicolumn{12}{|c|}{ Microelements (M) } \\
\hline \multicolumn{2}{|c|}{ Control (Tap water) } & 70.51 & 82.14 & 1383.8 & 2427.3 & 533.2 & 961.1 & 850.7 & 1466.2 & 10.47 & 14.58 \\
\hline \multicolumn{2}{|c|}{ Zn } & 76.07 & 86.60 & 2032.4 & 3360.5 & 838.3 & 1469.9 & 1194.1 & 1890.6 & 13.92 & 26.16 \\
\hline \multicolumn{2}{|l|}{ Mn } & 74.38 & 85.39 & 1855.7 & 3104.2 & 752.9 & 1330.7 & 1102.8 & 1773.5 & 12.03 & 23.34 \\
\hline \multicolumn{2}{|l|}{$\mathbf{Z n}+\mathbf{M n}$} & 77.95 & 87.96 & 2134.2 & 3521.3 & 897.9 & 1561.1 & 1236.3 & 1960.2 & 14.75 & 27.13 \\
\hline \multicolumn{2}{|l|}{ L.S.D at $5 \%$} & 2.63 & 2.83 & 136.7 & 158.7 & 76.8 & 87.9 & 79.6 & 87.8 & 2.11 & 2.99 \\
\hline \multicolumn{12}{|c|}{ Faba bean varieties (V) } \\
\hline \multicolumn{2}{|c|}{ Giza 716} & 68.49 & 80.35 & 1374.9 & 2338.8 & 525.5 & 936.3 & 849.4 & 1402.5 & 12.24 & 11.98 \\
\hline \multicolumn{2}{|l|}{ Nubaria 3} & 81.50 & 92.61 & 1783.1 & 3069.7 & 762.1 & 1384.5 & 1020.9 & 1685.2 & 11.73 & 26.01 \\
\hline \multicolumn{2}{|l|}{ Sakha 4} & 74.19 & 83.61 & 2396.7 & 3901.5 & 979.1 & 1671.3 & 1417.6 & 2230.2 & 14.40 & 30.42 \\
\hline \multicolumn{2}{|l|}{ L.S.D at 5\% } & 2.54 & 2.69 & 125.4 & 145.9 & 71.6 & 75.4 & 69.8 & 81.7 & 1.98 & 2.54 \\
\hline \multirow{4}{*}{$\begin{array}{l}\text { F test } \\
\text { Prob. }\end{array}$} & $\mathbf{P} \times \mathbf{M}$ & N.S. & N.S. & $* *$ & $* *$ & $* *$ & $* *$ & $* *$ & $* *$ & $* *$ & $* *$ \\
\hline & $\mathbf{P} \times \mathbf{V}$ & $* *$ & $* *$ & $* *$ & $* *$ & $* *$ & $* *$ & $* *$ & $* *$ & N.S. & N.S. \\
\hline & $\mathbf{M} \times \mathbf{V}$ & $* *$ & $* *$ & $* *$ & $* *$ & $* *$ & $* *$ & $* *$ & $* *$ & N.S. & N.S. \\
\hline & $\times \mathbf{M} \times \mathbf{V}$ & N.S. & N.S. & $* *$ & $* *$ & $* *$ & $* *$ & $* *$ & $* *$ & N.S. & N.S. \\
\hline
\end{tabular}

** Significant and N.S. No significant

Table 5. Mean values of seed $\mathrm{N}$ content, seed protein yield/fed, seed $\mathrm{P}$ content, seed $\mathrm{Zn}$ content and seed Mn content as affected by phosphorus fertilization rates, foliar spray by some microelements and varieties of faba bean during 2018/2019 $\left(1^{\text {st }}\right)$ and 2019/2020 $\left(2^{\text {nd }}\right)$ seasons.

\begin{tabular}{|c|c|c|c|c|c|c|c|c|c|c|c|}
\hline \multirow[t]{2}{*}{ Treatment } & \multirow{2}{*}{$\begin{array}{c}\text { Trait } \\
\text { Season }\end{array}$} & \multicolumn{2}{|c|}{$\begin{array}{c}\text { Seed N content } \\
(\%)\end{array}$} & \multicolumn{2}{|c|}{$\begin{array}{l}\text { Seed protein } \\
\text { yield (kg/fed) }\end{array}$} & \multicolumn{2}{|c|}{$\begin{array}{c}\text { Seed } P \text { content } \\
(\%)\end{array}$} & \multicolumn{2}{|c|}{$\begin{array}{c}\text { Seed } \mathrm{Zn} \text { content } \\
(\mathrm{mg} / \mathrm{kg})\end{array}$} & \multicolumn{2}{|c|}{$\begin{array}{c}\text { Seed Mn content } \\
(\mathrm{mg} / \mathrm{kg})\end{array}$} \\
\hline & & $\mathbf{1}^{\text {st }}$ & $2^{\text {nd }}$ & $1^{\text {st }}$ & $2^{\text {nd }}$ & $\mathbf{1}^{\text {st }}$ & $2^{\text {nd }}$ & $1^{\text {st }}$ & $2^{\text {nd }}$ & $1^{\text {st }}$ & $2^{\text {nd }}$ \\
\hline \multicolumn{12}{|c|}{ Phosphorus fertilization rates (P) } \\
\hline 0 & & 3.214 & 3.366 & 116.81 & 213.80 & 0.382 & 0.465 & 100.60 & 110.38 & 26.26 & 32.02 \\
\hline 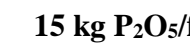 & & 3.500 & 3.616 & 178.19 & 321.85 & 0.569 & 0.615 & 101.53 & 111.11 & 26.68 & 32.60 \\
\hline $30 \mathrm{~kg} \mathrm{P}_{2} \mathrm{O}_{5} /$ & & 3.574 & 3.732 & 198.63 & 367.27 & 0.607 & 0.624 & 103.24 & 112.22 & 27.17 & 33.12 \\
\hline L.S.D at $5 \%$ & & N.S. & N.S. & 9.25 & 11.67 & 0.028 & 0.031 & N.S. & N.S. & N.S. & N.S. \\
\hline \multicolumn{12}{|c|}{ Microelements (M) } \\
\hline Control (Ta & p water) & 3.269 & 3.442 & 110.48 & 209.15 & 0.507 & 0.552 & 92.86 & 102.03 & 20.21 & 25.75 \\
\hline Zn & & 3.551 & 3.691 & 187.94 & 341.65 & 0.524 & 0.577 & 113.02 & 122.31 & 23.17 & 29.25 \\
\hline Mn & & 3.423 & 3.538 & 162.78 & 297.72 & 0.515 & 0.571 & 97.24 & 106.22 & 35.10 & 41.06 \\
\hline $\mathbf{Z n}+\mathbf{M n}$ & & 3.475 & 3.614 & 196.98 & 355.38 & 0.531 & 0.572 & 104.04 & 114.39 & 28.35 & 34.27 \\
\hline L.S.D at $5 \%$ & & N.S. & N.S. & 7.84 & 10.91 & N.S. & N.S. & 4.88 & 5.11 & 3.76 & 4.22 \\
\hline \multicolumn{12}{|c|}{ Faba bean varieties (V) } \\
\hline Giza 716 & & 3.490 & 3.653 & 116.36 & 216.28 & 0.519 & 0.567 & 99.61 & 108.47 & 25.64 & 31.01 \\
\hline Nubaria 3 & & 3.185 & 3.263 & 153.95 & 285.34 & 0.557 & 0.599 & 100.89 & 111.07 & 26.67 & 32.95 \\
\hline Sakha 4 & & 3.612 & 3.798 & 223.32 & 401.30 & 0.482 & 0.538 & 104.87 & 114.17 & 27.80 & 33.79 \\
\hline \multicolumn{2}{|l|}{ L.S.D at $5 \%$} & 0.115 & 0.136 & 6.35 & 7.83 & N.S. & N.S. & N.S. & N.S. & N.S. & N.S. \\
\hline \multirow{4}{*}{$\begin{array}{l}\text { F test } \\
\text { Prob. }\end{array}$} & $\mathbf{P} \times \mathbf{M}$ & N.S. & N.S. & $* *$ & $* *$ & $* *$ & $* *$ & $* *$ & $* *$ & $* *$ & $* *$ \\
\hline & $\mathbf{P} \times \mathbf{V}$ & N.S. & N.S. & $* *$ & $* *$ & $* *$ & $* *$ & N.S. & N.S. & N.S. & N.S. \\
\hline & $\mathbf{M} \times \mathbf{V}$ & N.S. & N.S. & $* *$ & $* *$ & N.S. & N.S. & $* *$ & $* *$ & $* *$ & $* *$ \\
\hline & $\times \mathbf{M} \times \mathbf{V}$ & N.S. & N.S. & N.S. & N.S. & N.S. & N.S. & N.S. & N.S. & N.S. & N.S. \\
\hline
\end{tabular}

** Significant and N.S. No significant 
Nubaria 3 variety significantly produced the maximum days to $50 \%$ physiological maturity (135.31 and 139.14 days), harvest index (42.29 and $44.50 \%)$ and 100 -seed weight (81.50 and $92.61 \mathrm{~g})$ in the both seasons, respectively.

The superiority ratios in the first season between faba bean variety of Nubaria 3 over each of Sakha 4 and Giza 716 were 4.39 and $11.94 \%$ for harvest in addition to 9.85 and $19.00 \%$ for 100 -seed weight, respectively. In the second season, the excess ratios when planting faba bean variety of Nubaria 3 over each of Sakha 4 and Giza 716 varieties were 4.88 and $12.23 \%$ for harvest index in addition to 10.76 and $15.26 \%$ for 100 -seed weight, respectively.

The shortest period from planting to $50 \%$ physiological maturity (132.31 and 134.56 days) was achieved by plant of Giza 716 variety during the both seasons, respectively.

These differences may be due to the genetic differences between faba bean varieties. Also, It could be concluded that faba bean variety of Sakha 4 surpassed the other faba bean varieties to increase seed yield/fed may be due to more likely attributed to the increases in chlorophyll content index, No. of pods/plant, No. of seeds/plant and seed yield/plant. These results are in agreement with those obtained by Abd AlKader et al. 2017; Al-Selawy et al. 2018; Mahdy and Ahmed 2018; El-Shafey et al. 2019; Kandil et al. 2019; Negasa et al. 2019; Al-Shumary 2020 and Nour El-Din et al. 2020, who reported marked differences in most vegetative growth, yield components, yield and seed chemical analysis among faba bean varieties.

\section{4- Effect of the interaction between phosphorus fertilization rates and foliar spray by microelements treatments:}

Results in Tables 6, 7 and 8 showed that the interaction effect between phosphorus fertilization rates $\left(0,15\right.$ and $30 \mathrm{~kg} \mathrm{P}_{2} \mathrm{O}_{5} /$ fed) and microelements foliar spray treatments (tap water, $\mathrm{Zn}, \mathrm{Mn}$ and $\mathrm{Zn}+$ $\mathrm{MN}$ ) induced significant differences on most vegetative growth, yield components, yield and seed chemical analysis of faba bean in the both seasons. While, No. of branches/plant, No. of pods/plant, 100seed weight and seed $\mathrm{N}$ content were insignificantly affected by the interaction during the two seasons, as shown in Tables 2, 3, 4 and 5.

Faba bean plants treated with $30 \quad \mathrm{P}_{2} \mathrm{O}_{5} /$ fed and foliar application with $\mathrm{Zn}+\mathrm{Mn}$ recorded the maximum plant height $(95.22$ and $111.16 \mathrm{~cm})$, plant weight (58.27 and $107.57 \mathrm{~g})$, No. of seeds/plant (30.99 and 53.87), seed yield/plant (25.21 and 49.06 g), harvest index (43.04 and $45.51 \%$ ), biological yield/fed (2430.7 and $3954.4 \mathrm{~kg})$, seed yield/fed
(1051.0 and $1807.9 \mathrm{~kg})$, straw yield/fed (1379.8 and $2146.5 \mathrm{~kg}$ ), seed protein yield/fed (238.97 and 426.51 $\mathrm{kg})$ and seed $\mathrm{P}$ content $(0.616$ and $0.632 \%)$ as well as gave significantly lower position of the $1^{\text {st }}$ pod $(14.30$ and $19.07 \mathrm{~cm})$ in the both seasons, respectively. On the other hand, the minimum chlorophyll content index at 85 DAS (27.77 and 30.39), plant height $(79.39$ and $91.44 \mathrm{~cm})$, plant weight (19.09 and $46.15 \mathrm{~g}$ ), No. of seeds/plant (1060 and 22.23), seed yield/plant (7.04 and $17.29 \mathrm{~g})$, harvest index (36.56 and $37.38 \%)$, biological yield/fed (1049.9 and $2006.9 \mathrm{~kg})$, seed yield/fed (387.01 and $751.2 \mathrm{~kg})$, straw yield/fed (662.8 and $1255.8 \mathrm{~kg})$, seed protein yield/fed (74.96 and 152.95 $\mathrm{kg}$ ), seed $\mathrm{P}$ content $(0.374$ and $0.454 \%)$, seed $\mathrm{Zn}$ content $(92.00$ and $101.21 \mathrm{mg} / \mathrm{kg})$ and seed $\mathrm{Mn}$ content $(20.00$ and $25.29 \mathrm{mg} / \mathrm{kg})$ in addition to higher position of the $1^{\text {st }}$ pod $(28.89$ and $31.94 \mathrm{~cm})$ were obtained from faba bean plants under without adding phosphorus fertilization or microelements (tap water) in the both seasons, respectively.

The shortest period from sowing to $50 \%$ physiological maturity (130.78 and 132.78 days) were recorded from faba bean treated with $30 \mathrm{~kg}$ $\mathrm{P}_{2} \mathrm{O}_{5} /$ fed and without microelements application (tap water) in the both seasons respectively. On the other hand, the longest period from sowing to $50 \%$ physiological maturity (137.22 and 141.55 days) was recorded from faba bean plants under without phosphorus added and foliar application with zinc in the both seasons respectively.

The maximum phosphorus use efficiency (17.47 and $33.54 \mathrm{~kg}$ seed $/ \mathrm{kg} \mathrm{P}_{2} \mathrm{O}_{5}$ applied) was recorded from faba bean treated with $15 \mathrm{~kg} \mathrm{P}_{2} \mathrm{O}_{5} / \mathrm{fed}$ and foliar application with $\mathrm{Zn}+\mathrm{Mn}$ in the both seasons respectively. On the other hand, the minimum mean values of phosphorus use efficiency (8.29 and 12.83 $\mathrm{kg}$ seed $/ \mathrm{kg} \mathrm{P}_{2} \mathrm{O}_{5}$ applied) were obtained from faba bean treated with $30 \mathrm{~kg} \quad \mathrm{P}_{2} \mathrm{O}_{5} /$ fed and without microelements application (tap water) in the both seasons respectively.

Faba bean plants treated with $30 \mathrm{~kg}_{2} \mathrm{O}_{5} /$ fed and foliar spray by singly $\mathrm{Zn}$ recorded the highest seed $\mathrm{Zn}$ content (116.38 and $123.92 \mathrm{mg} / \mathrm{kg}$ ), while with the same rate of phosphorus fertilization with foliar spray by singly $\mathrm{Mn}$ recorded the maximum chlorophyll content index at 85 DAS (37.66 and 42.40) and seed Mn content (35.85 and $41.90 \mathrm{mg} / \mathrm{kg}$ ) in the both seasons, respectively. The results reported here are in harmony with those obtained Weldua $\boldsymbol{e t}$ al. 2012; Desta et al. 2015; El-Agrodi et al. 2017; El-Sobky and Yasin 2017 and Ghazi 2017, who reported marked differences in mean values of most faba bean traits as affected by the interaction between phosphorus and microelements. 
Table 6. Mean values of chlorophyll content index at 85 DAS, days to $50 \%$ physiological maturity, plant height, height to $1^{\text {st }}$ pod and plant weight of faba bean as affected by the interaction between phosphorus fertilization rates and foliar spray by some microelements during 2018/2019 $\left(1^{\text {st }}\right)$ and 2019/2020 $\left(2^{\text {nd }}\right)$ seasons.

\begin{tabular}{|c|c|c|c|c|c|c|c|c|c|c|c|}
\hline \multirow[t]{2}{*}{ Treatment } & \multirow{2}{*}{$\begin{array}{c}\text { Trait } \\
\text { Season }\end{array}$} & \multicolumn{2}{|c|}{$\begin{array}{c}\text { Chlorophyll } \\
\text { content index at } \\
\text { 85 DAS } \\
\end{array}$} & \multicolumn{2}{|c|}{$\begin{array}{c}\text { Days to 50 \% } \\
\text { physiological } \\
\text { maturity (days) } \\
\end{array}$} & \multicolumn{2}{|c|}{ Plant height $(\mathrm{cm})$} & \multicolumn{2}{|c|}{$\begin{array}{l}\text { Height to } 1^{\text {st }} \text { pod } \\
(\mathrm{cm})\end{array}$} & \multicolumn{2}{|c|}{ Plant weight (g) } \\
\hline & & $1^{\text {st }}$ & $2^{\text {nd }}$ & $1^{\text {st }}$ & $2^{\text {nd }}$ & $1^{\text {st }}$ & $2^{\text {nd }}$ & $1^{\text {st }}$ & $2^{\text {nd }}$ & $1^{\text {st }}$ & $2^{\text {nd }}$ \\
\hline \multirow{4}{*}{ 0 } & Control & 27.77 & 30.39 & 133.22 & 136.78 & 79.39 & 91.44 & 28.89 & 31.94 & 19.09 & 46.15 \\
\hline & Zn & 29.88 & 32.92 & 137.22 & 141.55 & 86.42 & 101.14 & 24.14 & 26.40 & 30.08 & 62.25 \\
\hline & Mn & 33.45 & 36.92 & 135.00 & 139.89 & 84.22 & 96.96 & 26.47 & 28.67 & 27.71 & 58.91 \\
\hline & $\mathbf{Z n}+\mathbf{M n}$ & 31.80 & 34.61 & 136.33 & 140.89 & 88.38 & 103.91 & 22.32 & 24.37 & 32.01 & 66.59 \\
\hline \multirow{4}{*}{15} & Control & 32.14 & 36.00 & 131.67 & 133.67 & 83.50 & 97.85 & 21.60 & 26.61 & 31.64 & 70.63 \\
\hline & $\mathbf{Z n}$ & 34.25 & 38.08 & 134.67 & 137.78 & 91.52 & 106.86 & 18.24 & 23.03 & 46.76 & 90.05 \\
\hline & Mn & 36.12 & 39.87 & 133.67 & 136.78 & 88.96 & 100.47 & 19.35 & 24.01 & 40.86 & 83.98 \\
\hline & $\mathbf{Z n}+\mathbf{M n}$ & 35.34 & 38.99 & 134.11 & 137.00 & 93.64 & 110.55 & 17.07 & 20.94 & 48.33 & 94.30 \\
\hline \multirow{4}{*}{30} & Control & 34.43 & 38.77 & 130.78 & 132.78 & 86.21 & 100.48 & 20.07 & 23.44 & 35.69 & 81.14 \\
\hline & Zn & 35.17 & 40.10 & 133.44 & 135.67 & 92.65 & 106.74 & 16.24 & 20.46 & 51.96 & 100.17 \\
\hline & Mn & 37.66 & 42.40 & 131.89 & 134.11 & 90.52 & 104.36 & 17.74 & 21.22 & 48.51 & 89.58 \\
\hline & $\mathbf{Z n}+\mathbf{M n}$ & 36.12 & 40.98 & 132.45 & 134.78 & 95.22 & 111.16 & 14.30 & 19.07 & 58.27 & 107.57 \\
\hline \multicolumn{2}{|c|}{ L.S.D at $5 \%$} & 1.51 & 1.66 & 2.79 & 3.03 & 3.66 & 4.07 & 2.17 & 2.23 & 8.00 & 10.18 \\
\hline
\end{tabular}

Table 7. Mean values in No. of seeds/plant, seed yield/plant, harvest index, biological yield/fed and seed yield/fed of faba bean as affected by the interaction between phosphorus fertilization rates and foliar spray by some microelements during 2018/2019 $\left(1^{\text {st }}\right)$ and 2019/2020 $\left(2^{\text {nd }}\right)$ seasons.

\begin{tabular}{|c|c|c|c|c|c|c|c|c|c|c|c|}
\hline \multirow{2}{*}{ Treatment } & \multirow{2}{*}{$\begin{array}{c}\text { Trait } \\
\text { Season }\end{array}$} & \multicolumn{2}{|c|}{$\begin{array}{c}\text { No. of } \\
\text { seeds/plant }\end{array}$} & \multicolumn{2}{|c|}{$\begin{array}{c}\text { Seed yield/plant } \\
(\mathrm{g})\end{array}$} & \multicolumn{2}{|c|}{$\begin{array}{c}\text { Harvest index } \\
(\%)\end{array}$} & \multicolumn{2}{|c|}{$\begin{array}{c}\text { Biological yield } \\
(\mathrm{kg} / \mathrm{fed})\end{array}$} & \multicolumn{2}{|c|}{$\begin{array}{c}\text { Seed yield } \\
(\mathrm{kg} / \mathrm{fed})\end{array}$} \\
\hline & & $1^{\text {st }}$ & $2^{\text {nd }}$ & $1^{\text {st }}$ & $2^{\text {nd }}$ & $1^{\text {st }}$ & $2^{\text {nd }}$ & $1^{\text {st }}$ & $2^{\text {nd }}$ & $1^{\mathrm{st}}$ & $2^{\text {nd }}$ \\
\hline & Control & 10.60 & 22.23 & & & 36.56 & & 1049.9 & 2006.9 & 387.1 & 751.2 \\
\hline & $\mathbf{Z n}$ & 16.05 & 30.97 & 11.76 & 25.48 & 38.84 & 40.64 & 1654.3 & 2692.6 & 647.0 & 1101.2 \\
\hline & Mn & 14.78 & 29.30 & 10.60 & 23.67 & 38.00 & 39.86 & 1523.9 & 2495.1 & 583.0 & 1002.1 \\
\hline & $\mathbf{Z n}+\mathbf{M n}$ & 17.14 & 32.92 & 12.73 & 27.63 & 39.44 & 41.20 & 1736.8 & 2862.7 & 690.3 & 1186.2 \\
\hline \multirow{4}{*}{15} & Control & 17.25 & 33.66 & 12.20 & 27.92 & 38.45 & 39.34 & 1495.6 & 2516.0 & 576.7 & 996.2 \\
\hline & Zn & 25.16 & 45.15 & 19.50 & 39.96 & 41.47 & 44.26 & 2182.4 & 3520.2 & 908.3 & 1564.5 \\
\hline & Mn & 22.23 & 41.75 & 16.77 & 36.34 & 40.77 & 43.26 & 1939.0 & 3271.0 & 795.0 & 1416.8 \\
\hline & $\mathbf{Z n}+\mathbf{M n}$ & 25.98 & 47.55 & 20.62 & 42.45 & 42.44 & 44.84 & 2235.1 & 3746.7 & 952.3 & 1689.2 \\
\hline \multirow{4}{*}{30} & Control & 18.71 & 39.06 & 14.13 & 33.39 & 39.41 & 40.94 & 1606.0 & 2758.9 & 635.7 & 1135.9 \\
\hline & $\mathbf{Z n}$ & 28.15 & 50.39 & 22.06 & 45.02 & 42.25 & 44.87 & 2260.5 & 3868.7 & 959.5 & 1744.1 \\
\hline & Mn & 26.46 & 44.84 & 20.31 & 39.63 & 41.61 & 44.22 & 2104.2 & 3546.4 & 880.8 & 1573.2 \\
\hline & $\mathbf{Z n}+\mathbf{M n}$ & 30.99 & 53.87 & 25.21 & 49.06 & 43.04 & 45.51 & 2430.7 & 3954.4 & 1051.0 & 1807.9 \\
\hline \multicolumn{2}{|c|}{ L.S.D at $5 \%$} & 4.38 & 5.47 & 4.12 & 4.71 & 1.09 & 1.25 & 236.8 & 274.9 & 133.0 & 152.2 \\
\hline
\end{tabular}


Table 8. Mean values of straw yield/fed, phosphorus use efficiency, seed protein yield/fed, seed P content, seed $\mathrm{Zn}$ content and seed Mn content of faba bean as affected by the interaction between phosphorus fertilization rates and foliar spray by some microelements during 2018/2019 (1 $\left.1^{\text {st }}\right)$ and 2019/2020 $\left(2^{\text {nd }}\right)$ seasons.

\begin{tabular}{|c|c|c|c|c|c|c|c|c|c|c|c|c|c|}
\hline \multirow[t]{2}{*}{ Treatment } & \multirow{2}{*}{$\begin{array}{c}\text { Trait } \\
\text { Season }\end{array}$} & \multicolumn{2}{|c|}{$\begin{array}{l}\text { Straw yield } \\
(\mathrm{kg} / \mathrm{fed})\end{array}$} & \multicolumn{2}{|c|}{$\begin{array}{l}\text { Phosphorus } \\
\text { use efficiency }\end{array}$} & \multicolumn{2}{|c|}{$\begin{array}{l}\text { Seed protein } \\
\text { yield (kg/fed) }\end{array}$} & \multicolumn{2}{|c|}{$\begin{array}{c}\text { Seed } P \text { content } \\
(\%)\end{array}$} & \multicolumn{2}{|c|}{$\begin{array}{c}\text { Seed Zn } \\
\text { content } \\
(\mathrm{mg} / \mathrm{kg})\end{array}$} & \multicolumn{2}{|c|}{$\begin{array}{c}\text { Seed Mn } \\
\text { content } \\
(\mathrm{mg} / \mathrm{kg}) \\
\end{array}$} \\
\hline & & $1^{\text {st }}$ & $2^{\text {nd }}$ & $1^{\text {st }}$ & $2^{\text {nd }}$ & $1^{\text {st }}$ & $2^{\text {nd }}$ & $1^{\text {st }}$ & $2^{\text {nd }}$ & $1^{\text {st }}$ & $2^{\text {nd }}$ & $1^{\text {st }}$ & $2^{\text {nd }}$ \\
\hline \multirow{4}{*}{ 0 } & Control & 662.8 & 1255.8 & -- & -- & 74.96 & 152.95 & 0.374 & 0.454 & 92.00 & 101.21 & 20.00 & 25.29 \\
\hline & Zn & 1007.3 & 1591.4 & -- & -- & 135.06 & 240.57 & 0.385 & 0.468 & 110.61 & 121.08 & 22.86 & 28.77 \\
\hline & Mn & 940.9 & 1493.1 & -- & -- & 116.74 & 209.19 & 0.372 & 0.464 & 96.43 & 105.52 & 34.36 & 40.19 \\
\hline & $\mathbf{Z n}+\mathbf{M n}$ & 1046.5 & 1676.6 & -- & -- & 140.47 & 252.50 & 0.395 & 0.475 & 103.36 & 113.71 & 27.84 & 33.85 \\
\hline \multirow{4}{*}{15} & Control & 919.0 & 1519.9 & 12.64 & 16.33 & 121.07 & 217.72 & 0.552 & 0.587 & 92.87 & 101.93 & 20.22 & 25.77 \\
\hline & $\mathbf{Z n}$ & 1274.0 & 1955.7 & 17.42 & 30.88 & 206.00 & 365.67 & 0.576 & 0.635 & 112.05 & 121.93 & 23.10 & 29.26 \\
\hline & Mn & 1144.0 & 1854.1 & 14.13 & 27.65 & 174.20 & 316.89 & 0.569 & 0.628 & 97.23 & 106.21 & 35.08 & 41.10 \\
\hline & $\mathbf{Z n}+\mathbf{M n}$ & 1282.8 & 2057.5 & 17.47 & 33.54 & 211.49 & 387.13 & 0.581 & 0.609 & 103.95 & 114.38 & 28.33 & 34.29 \\
\hline \multirow{4}{*}{30} & Control & 970.2 & 1623.0 & 8.29 & 12.83 & 135.41 & 256.78 & 0.595 & 0.615 & 93.70 & 102.94 & 20.40 & 26.20 \\
\hline & $\mathbf{Z n}$ & 1300.9 & 2124.6 & 10.42 & 21.43 & 222.76 & 418.70 & 0.612 & 0.626 & 116.38 & 123.92 & 23.54 & 29.73 \\
\hline & Mn & 1223.4 & 1973.2 & 9.93 & 19.04 & 197.39 & 367.07 & 0.605 & 0.621 & 98.07 & 106.93 & 35.85 & 41.90 \\
\hline & $\mathbf{Z n}+\mathbf{M n}$ & 1379.8 & 2146.5 & 12.02 & 20.72 & 238.97 & 426.51 & 0.616 & 0.632 & 104.80 & 115.07 & 28.88 & 34.66 \\
\hline \multicolumn{2}{|c|}{ L.S.D at $5 \%$} & 4.40 & 4.66 & 2.98 & 4.23 & 13.58 & 18.90 & 0.043 & 0.047 & 8.45 & 8.85 & 6.51 & 7.31 \\
\hline
\end{tabular}

5- Effect of the interaction between phosphorus fertilization rates and faba bean varieties:

Interaction effect between phosphorus fertilization rates $\left(0,15\right.$ and $30 \mathrm{~kg} \mathrm{P}_{2} \mathrm{O}_{5} /$ fed $)$ and faba bean varieties (Giza 716, Nubaria 3 and Sakha 4) was significant on most vegetative growth, yield components, yield and seed chemical analysis in 2018/2019 and 2019/2020 seasons, as shown in Tables 9, 10 and 11. Meanwhile, days to $50 \%$ physiological maturity, phosphorus use efficiency, seed $\mathrm{N}$ content, seed $\mathrm{Zn}$ content and seed Mn content were insignificantly affected by the interaction in the two growing seasons, as shown in as shown in Tables 2, 4 and 5.

Sakha 4 variety treated with $30 \mathrm{~kg} \mathrm{P}_{2} \mathrm{O}_{5} /$ fed gave the greatest chlorophyll content index at 85 DAS (39.74 and 44.42), plant height (103.24 and 114.05 $\mathrm{cm}$ ), No. of branches/plant (3.763 and 4.633), plant weight (64.06 and $115.64 \mathrm{~g})$, No. of pods/plant (9.978 and 15.043), No. of seeds/plant (35.11 and 58.31), seed yield/plant (27.01 and $50.85 \mathrm{~g})$, biological yield/fed $(2707.0$ and $4532.9 \mathrm{~kg})$, seed yield/fed (1140.4 and $1994.3 \mathrm{~kg}$ ), straw yield/fed $(1566.6$ and $2538.6 \mathrm{~kg})$ and seed protein yield/fed $(267.77$ and $497.14 \mathrm{~kg})$ in the two seasons respectively. On the other hand, the lowest chlorophyll content index at 85 DAS (27.83 and $31.42)$, plant height $(73.87$ and $91.49 \mathrm{~cm})$ and No. of branches/plant (1.230 and 1.778) were obtained from
Nubaria 3 variety under without phosphorus application in the both seasons, respectively. While, Giza 716 variety without phosphorus applied recorded the minimum plant weight (17.99 and 45.53 g), No. of pods/plant (3.165 and 6.533), No. of seeds/plant (9.99 and 22.38), seed yield/plant (6.51 and $17.05 \mathrm{~g}$ ), harvest index (35.95 and $37.27 \%$ ), 100-seed weight (64.59 and $75.95 \mathrm{~g})$, biological yield/fed (989.8 and $2037.8 \mathrm{~kg}$ ), seed yield/fed (358.1 and $762.9 \mathrm{~kg})$, straw yield/fed (631.7 and $1274.9 \mathrm{~kg})$ and seed protein yield/fed (73.98 and $164.80 \mathrm{~kg})$ in the two seasons respectively.

Nubaria 3 variety treated with $30 \mathrm{~kg} \mathrm{P}_{2} \mathrm{O}_{5} / \mathrm{fed}$ produced the maximum harvest index (43.72 and $46.64 \%)$, 100-seed weight $(85.22$ and $95.07 \mathrm{~g})$ and seed $\mathrm{P}$ content $(0.643$ and $0.656 \%)$ in addition to the lowest height to $1^{\text {st }}$ pod $(14.52$ and $17.06 \mathrm{~cm})$ in the both seasons, respectively. Sakha 4 variety without phosphorus application gave the higher position of the $1^{\text {st }}$ pod $(28.88$ and $31.10 \mathrm{~cm})$ as well as the lowest seed $\mathrm{P}$ content $(0.351$ and $0.431 \%)$ respective in the both seasons.

These results are in agreement with that obtained by Nebiyu et al. 2016; Abd AlKader et al. 2017; Kandil et al. 2019 and Negasa et al. 2019, found that most faba bean traits were significantly affected by interaction between phosphorus and faba bean varieties. 
Table 9. Mean values of chlorophyll content index at 85 DAS, plant height, height to $1^{\text {st }}$ pod, No. of branches/plant and plant weight as affected by the interaction between phosphorus fertilization rates and faba bean varieties during 2018/2019 $\left(1^{\text {st }}\right)$ and 2019/2020 $\left(2^{\text {nd }}\right)$ seasons.

\begin{tabular}{|c|c|c|c|c|c|c|c|c|c|c|c|}
\hline \multirow[t]{2}{*}{ Treatment } & \multirow{2}{*}{$\begin{array}{c}\text { Trait } \\
\text { Season }\end{array}$} & \multicolumn{2}{|c|}{$\begin{array}{c}\text { Chlorophyll } \\
\text { content index at } \\
85 \text { DAS } \\
\end{array}$} & \multicolumn{2}{|c|}{ Plant height (cm) } & \multicolumn{2}{|c|}{$\begin{array}{c}\text { Height to } 1^{\text {st }} \text { pod } \\
(\mathrm{cm})\end{array}$} & \multicolumn{2}{|c|}{$\begin{array}{c}\text { No. of } \\
\text { branches/plant }\end{array}$} & \multicolumn{2}{|c|}{ Plant weight (g) } \\
\hline & & $1^{\text {st }}$ & $2^{\text {nd }}$ & $1^{\text {st }}$ & $2^{\text {nd }}$ & $1^{\text {st }}$ & $2^{\text {nd }}$ & $1^{\text {st }}$ & $2^{\text {nd }}$ & $1^{\text {st }}$ & $2^{\text {nd }}$ \\
\hline \multirow{3}{*}{$\mathbf{0}$} & Giza 716 & 30.91 & 33.08 & 83.53 & 95.39 & 26.39 & 29.51 & 1.498 & 2.035 & 17.99 & 45.53 \\
\hline & Nubaria 3 & 27.83 & 31.42 & 73.87 & 91.49 & 21.09 & 22.93 & 1.230 & 1.778 & 26.96 & 58.38 \\
\hline & Sakha 4 & 33.45 & 36.63 & 96.41 & 108.21 & 28.88 & 31.10 & 1.838 & 2.685 & 36.72 & 71.52 \\
\hline \multirow{3}{*}{15} & Giza 716 & 34.80 & 37.97 & 87.90 & 102.29 & 19.92 & 25.08 & 2.968 & 3.715 & 30.87 & 65.66 \\
\hline & Nubaria 3 & 30.08 & 34.18 & 78.85 & 97.16 & 15.54 & 19.17 & 2.143 & 3.040 & 40.08 & 81.93 \\
\hline & Sakha 4 & 38.51 & 42.56 & 101.47 & 112.35 & 21.74 & 26.70 & 3.378 & 4.200 & 54.75 & 106.64 \\
\hline \multirow{3}{*}{$\mathbf{N}$} & Giza 716 & 36.46 & 40.43 & 89.18 & 104.72 & 17.08 & 21.69 & 3.255 & 4.360 & 36.28 & 78.37 \\
\hline & Nubaria 3 & 31.34 & 36.83 & 81.04 & 98.28 & 14.52 & 17.06 & 2.493 & 3.395 & 45.49 & 89.85 \\
\hline & Sakha 4 & 39.74 & 44.42 & 103.24 & 114.05 & 19.66 & 24.39 & 3.763 & 4.633 & 64.06 & 115.64 \\
\hline \multicolumn{2}{|c|}{ L.S.D at 5\% } & 1.13 & 1.54 & 3.43 & 3.72 & 1.77 & 1.92 & 0.546 & 0.663 & 7.29 & 8.63 \\
\hline
\end{tabular}

Table 10. Mean values in No. of pods/plant, No. of seeds/plant, seed yield/plant, harvest index and 100-seed weight as affected by the interaction between phosphorus fertilization rates and faba bean varieties during $2018 / 2019\left(1^{\text {st }}\right)$ and 2019/2020 $\left(2^{\text {nd }}\right)$ seasons.

\begin{tabular}{|c|c|c|c|c|c|c|c|c|c|c|c|}
\hline \multirow{2}{*}{ Treatment } & \multirow{2}{*}{$\begin{array}{c}\text { Trait } \\
\text { Season }\end{array}$} & \multicolumn{2}{|c|}{ No. of pods/plant } & \multicolumn{2}{|c|}{ No. of seeds/plant } & \multicolumn{2}{|c|}{$\begin{array}{c}\text { Seed yield/plant } \\
(\mathrm{g})\end{array}$} & \multicolumn{2}{|c|}{$\begin{array}{c}\text { Harvest index } \\
(\%)\end{array}$} & \multicolumn{2}{|c|}{$\begin{array}{c}\text { 100-seed weight } \\
\text { (g) }\end{array}$} \\
\hline & & $1^{\text {st }}$ & $2^{\text {nd }}$ & $1^{\text {st }}$ & $2^{\text {nd }}$ & $1^{\text {st }}$ & $2^{\text {nd }}$ & $\mathbf{1}^{\text {st }}$ & $2^{\text {nd }}$ & $1^{\text {st }}$ & $2^{\text {nd }}$ \\
\hline \multirow{3}{*}{$\mathbf{0}$} & Giza 716 & 3.165 & 6.533 & 9.99 & 22.38 & 6.51 & 17.05 & 35.95 & 37.27 & 64.59 & 75.95 \\
\hline & Nubaria 3 & 4.843 & 8.535 & 14.03 & 27.06 & 10.88 & 24.11 & 40.16 & 41.14 & 76.96 & 88.75 \\
\hline & Sakha 4 & 5.860 & 10.270 & 19.90 & 37.13 & 14.21 & 29.39 & 38.52 & 40.90 & 70.94 & 78.90 \\
\hline \multirow{3}{*}{15} & Giza 716 & 5.353 & 9.373 & 17.08 & 32.67 & 11.89 & 26.73 & 38.33 & 40.48 & 69.15 & 81.52 \\
\hline & Nubaria 3 & 7.238 & 12.345 & 20.89 & 39.96 & 17.37 & 37.71 & 42.99 & 45.74 & 82.33 & 94.02 \\
\hline & Sakha 4 & 8.668 & 14.343 & 29.99 & 53.46 & 22.56 & 45.56 & 41.03 & 42.56 & 74.91 & 84.98 \\
\hline \multirow{3}{*}{30} & Giza 716 & 5.980 & 10.810 & 19.74 & 38.69 & 14.24 & 32.43 & 39.04 & 41.20 & 71.74 & 83.59 \\
\hline & Nubaria 3 & 7.698 & 13.338 & 23.40 & 44.12 & 20.04 & 42.05 & 43.72 & 46.64 & 85.22 & 95.07 \\
\hline & Sakha 4 & 9.978 & 15.403 & 35.11 & 58.31 & 27.01 & 50.85 & 41.97 & 43.82 & 76.73 & 86.95 \\
\hline \multicolumn{2}{|c|}{ L.S.D at 5\% } & 2.179 & 2.485 & 4.23 & 4.92 & 3.79 & 4.30 & 1.06 & 1.20 & 4.40 & 4.66 \\
\hline
\end{tabular}

Table 11. Mean values of biological yield/fed, seed yield/fed, straw yield/fed, seed protein yield/fed and seed $P$ content as affected by the interaction between phosphorus fertilization rates and faba bean varieties during 2018/2019 $\left(1^{\text {st }}\right)$ and 2019/2020 $\left(2^{\text {nd }}\right)$ seasons.

\begin{tabular}{|c|c|c|c|c|c|c|c|c|c|c|c|}
\hline \multirow[t]{2}{*}{ Treatment } & \multirow{2}{*}{$\begin{array}{c}\text { Trait } \\
\text { Season }\end{array}$} & \multicolumn{2}{|c|}{$\begin{array}{c}\text { Biological yield } \\
\text { (kg/fed) }\end{array}$} & \multicolumn{2}{|c|}{ Seed yield $(\mathrm{kg} / \mathrm{fed})$} & \multicolumn{2}{|c|}{$\begin{array}{c}\text { Straw yield } \\
(\mathrm{kg} / \mathrm{fed})\end{array}$} & \multicolumn{2}{|c|}{$\begin{array}{l}\text { Seed protein yield } \\
(\mathrm{kg} / \mathrm{fed})\end{array}$} & \multicolumn{2}{|c|}{$\begin{array}{c}\text { Seed P content } \\
(\%)\end{array}$} \\
\hline & & $\mathbf{1}^{\text {st }}$ & $2^{\text {nd }}$ & $1^{\text {st }}$ & $2^{\text {nd }}$ & $1^{\text {st }}$ & $2^{\text {nd }}$ & $1^{\text {st }}$ & $2^{\text {nd }}$ & $1^{\text {st }}$ & $2^{\text {nd }}$ \\
\hline \multirow{3}{*}{$\mathbf{0}$} & Giza 716 & 989.8 & 2037.8 & 358.1 & 762.9 & 631.7 & 1274.9 & 73.98 & 164.80 & 0.375 & 0.455 \\
\hline & Nubaria 3 & 1482.6 & 2485.1 & 598.4 & 1026.0 & 884.2 & 1459.2 & 110.87 & 198.22 & 0.420 & 0.511 \\
\hline & Sakha 4 & 2001.3 & 3020.2 & 774.1 & 1241.6 & 1227.2 & 1778.6 & 165.58 & 278.39 & 0.351 & 0.431 \\
\hline \multirow{3}{*}{15} & Giza 716 & 1533.3 & 2359.7 & 590.4 & 961.6 & 942.9 & 1398.1 & 131.90 & 223.16 & 0.570 & 0.613 \\
\hline & Nubaria 3 & 1874.1 & 3279.5 & 811.1 & 1510.5 & 1063.0 & 1769.0 & 166.05 & 314.02 & 0.607 & 0.630 \\
\hline & Sakha 4 & 2481.7 & 4151.3 & 1022.8 & 1777.9 & 1459.0 & 2373.4 & 236.62 & & 0.531 & 0.602 \\
\hline \multirow{3}{*}{30} & Giza 716 & 1601.6 & 2619.0 & 628.1 & 1084.4 & 973.5 & 1534.6 & 143.19 & 260.88 & 0.613 & 0.633 \\
\hline & Nubaria 3 & 1992.5 & 3444.5 & 876.8 & 1617.2 & 1115.7 & 1827.3 & 184.94 & 343.77 & 0.643 & 0.656 \\
\hline & Sakha 4 & 2707.0 & 4532.9 & 1140.4 & 1994.3 & 1566.6 & 2538.6 & 267.77 & 497.14 & 0.565 & 0.582 \\
\hline \multicolumn{2}{|c|}{ L.S.D at $5 \%$} & 217.2 & 252.7 & 124.0 & 130.6 & 120.9 & 141.5 & 11.00 & 13.56 & 0.042 & 0.043 \\
\hline
\end{tabular}


6- Effect of the interaction between foliar spray by microelements treatments and faba bean varieties:

Results in Tables 12 and 13 indicated that chlorophyll content index at 85 DAS, plant height $(\mathrm{cm})$, plant weight $(\mathrm{g})$, No. of seeds/plant, seed yield/plant $(\mathrm{g})$, 100-seed weight $(\mathrm{g})$, biological yield/fed $(\mathrm{kg})$, seed yield/fed $(\mathrm{kg})$, straw yield/fed $(\mathrm{kg})$, seed protein yield/fed $(\mathrm{kg})$, seed $\mathrm{Zn}$ content $(\mathrm{mg} / \mathrm{kg})$ and seed $\mathrm{Mn}$ content $(\mathrm{mg} / \mathrm{kg})$ were significantly affected by the interaction between foliar spray by microelements treatments (tap water, $\mathrm{Zn}, \mathrm{Mn}$ and $\mathrm{Zn}+\mathrm{Mn}$ ) and faba bean varieties (Giza 716, Nubaria 3 and Sakha 4) during the both seasons. While, physiological maturity, height to $1^{\text {st }}$ pod, No. of branches/plant, No. of pods/plant, harvest index, phosphorus use efficiency, seed $\mathrm{N}$ content and seed $\mathrm{P}$ content were insignificantly affected by the interaction in the both seasons, as shown in Tables 2 , 3,4 and 5.

Sakha 4 plants treated with mixed foliar application of $\mathrm{Zn}+\mathrm{Mn}$ produced the greatest plant height $(103.87$ and $118.88 \mathrm{~cm})$, plant weight $(59.02$ and $109.18 \mathrm{~g}$ ), No. of seeds/plant (31.95 and 56.01), seed yield/plant (24.89 and $48.68 \mathrm{~g})$, biological yield/fed (2704.8 and $4316.3 \mathrm{~kg}$ ), seed yield/fed (1137.7 and $1921.9 \mathrm{~kg})$, straw yield/fed (1567.1 and $2394.4 \mathrm{~kg}$ ) and seed protein yield/fed (261.60 and $464.00 \mathrm{~kg}$ ) in the respective both seasons. Meanwhile, with the same faba bean variety and foliar spray by singly $\mathrm{Zn}$ recorded the highest seed $\mathrm{Zn}$ content (115.63 and $125.64 \mathrm{mg} / \mathrm{kg}$ ) and with foliar spray by singly $\mathrm{Mn}$ recorded the highest chlorophyll content index at 85 DAS (39.82 and 43.69) and seed Mn content (36.27 and $42.49 \mathrm{mg} / \mathrm{kg}$ ) in the both seasons, respectively. On the other hand, the minimum chlorophyll content index at 85 DAS (27.80 and 32.08), plant height (72.02 and $89.26 \mathrm{~cm})$ were recorded from faba bean variety of Nubaria 3 without microelements application (tap water) in the both seasons respectively. While, the lowest plant weight (20.62 and $50.37 \mathrm{~g}$ ), No. of seeds/plant (11.49 and 24.07), seed yield/plant (7.51 and $18.79 \mathrm{~g}), 100$ seed weight (64.37 and $77.39 \mathrm{~g})$, biological yield/fed (1005.4 and $1847.5 \mathrm{~kg}$ ), seed yield/fed (365.6 and $686.0 \mathrm{~kg}$ ), straw yield/fed $(639.9$ and $1161.6 \mathrm{~kg})$, seed protein yield/fed (76.85 and $149.69 \mathrm{~kg})$, seed $\mathrm{Zn}$ content $(91.22$ and $99.77 \mathrm{mg} / \mathrm{kg})$ and seed $\mathrm{Mn}$ content $(19.77$ and $24.73 \mathrm{mg} / \mathrm{kg})$ in the two seasons, respectively.

Nubaria 3 variety treated with mixed foliar application of $\mathrm{Zn}+\mathrm{Mn}$ gave the heaviest 100-seed weight (84.92 and $95.36 \mathrm{~g})$ in the both seasons, respectively. The results reported here are in harmony with those obtained Mekkei 2014; Jarecki et al., 2016; El-Shafey et al. 2019; Al-Shumary 2020 and Nour El-Din et al. 2020, found that most faba bean traits were significantly affected by interaction between microelements application and faba bean varieties.

Table 12. Mean values of chlorophyll content index at 85 DAS, plant height, plant weight, No. of seeds/plant, seed yield/plant, 100-seed weight as affected by the interaction between foliar spray by some microelements and faba bean varieties during 2018/2019 $\left(1^{\text {st }}\right)$ and 2019/2020 $\left(2^{\text {nd }}\right)$ seasons.

\begin{tabular}{|c|c|c|c|c|c|c|c|c|c|c|c|c|c|}
\hline \multirow[t]{2}{*}{ Treatmen } & \multirow{2}{*}{$\begin{array}{c}\text { Trait } \\
\text { Season }\end{array}$} & \multicolumn{2}{|c|}{$\begin{array}{l}\text { Chlorophyll } \\
\text { content index } \\
\text { at } 85 \text { DAS }\end{array}$} & \multicolumn{2}{|c|}{$\begin{array}{l}\text { Plant height } \\
\text { (cm) }\end{array}$} & \multicolumn{2}{|c|}{$\begin{array}{c}\text { Plant weight } \\
\text { (g) }\end{array}$} & \multicolumn{2}{|c|}{$\begin{array}{c}\text { No. of } \\
\text { seeds/plant }\end{array}$} & \multicolumn{2}{|c|}{$\begin{array}{c}\text { Seed } \\
\text { yield/plant (g) }\end{array}$} & \multicolumn{2}{|c|}{$\begin{array}{c}\text { 100-seed } \\
\text { weight } \\
(\mathrm{g})\end{array}$} \\
\hline & & $\mathbf{1}^{\text {st }}$ & $2^{\text {nd }}$ & $1^{\text {st }}$ & $2^{\text {nd }}$ & $1^{\text {st }}$ & $2^{\text {nd }}$ & $1^{\text {st }}$ & $2^{\text {nd }}$ & $1^{\text {st }}$ & $2^{\text {nd }}$ & $1^{\text {st }}$ & $2^{\text {nd }}$ \\
\hline \multirow{3}{*}{ Control } & Giza 716 & 32.00 & 34.32 & 81.27 & 95.39 & 20.62 & 50.37 & 11.49 & 24.07 & 7.51 & 18.79 & 64.37 & 77.39 \\
\hline & Nubaria 3 & 27.80 & 32.08 & 72.02 & 89.26 & 25.96 & 63.43 & 13.49 & 29.31 & 10.43 & 26.31 & 76.45 & 89.15 \\
\hline & Sakha 4 & 34.55 & 38.76 & 95.81 & 105.12 & 39.84 & 84.13 & 21.59 & 41.57 & 15.42 & 33.50 & 70.73 & 79.87 \\
\hline \multirow{3}{*}{$\mathbf{Z n}$} & Giza 716 & 33.72 & 36.67 & 88.88 & 102.09 & 31.20 & 68.20 & 17.17 & 34.05 & 12.08 & 27.94 & 69.66 & 81.38 \\
\hline & Nubaria 3 & 29.31 & 34.00 & 79.84 & 97.91 & 41.39 & 81.62 & 21.44 & 40.09 & 17.96 & 37.68 & 83.22 & 93.45 \\
\hline & Sakha 4 & 36.28 & 40.43 & 101.88 & 114.73 & 56.22 & 102.66 & 30.74 & 52.37 & 23.29 & 44.83 & 75.34 & 84.99 \\
\hline \multirow{3}{*}{ Mn } & Giza 716 & 35.76 & 39.68 & 86.28 & 99.68 & 27.49 & 62.51 & 15.17 & 31.04 & 10.47 & 25.17 & 68.38 & 80.36 \\
\hline & Nubaria 3 & 31.64 & 35.82 & 77.48 & 94.71 & 37.30 & 74.21 & 19.25 & 36.27 & 15.79 & 33.75 & 81.42 & 92.50 \\
\hline & Sakha 4 & 39.82 & 43.69 & 99.94 & 107.40 & 52.29 & 95.75 & 29.05 & 48.57 & 21.42 & 40.72 & 73.34 & 83.31 \\
\hline \multirow{3}{*}{$\begin{array}{c}\text { Zn } \\
+ \\
\mathbf{M N}\end{array}$} & Giza 716 & 34.75 & 37.97 & 91.04 & 106.05 & 34.21 & 71.67 & 18.59 & 35.83 & 13.45 & 29.72 & 71.56 & 82.27 \\
\hline & Nubaria 3 & 30.23 & 34.68 & 82.34 & 100.69 & 45.38 & 87.62 & 23.57 & 42.51 & 20.21 & 40.74 & 84.92 & 95.36 \\
\hline & Sakha 4 & 38.27 & 41.93 & 103.87 & 118.88 & 59.02 & 109.18 & 31.95 & 56.01 & 24.89 & 48.68 & 77.35 & 86.26 \\
\hline \multicolumn{2}{|c|}{ L.S.D at $5 \%$} & 1.30 & 1.78 & 3.96 & 4.30 & 8.42 & 9.96 & 4.88 & 5.68 & 4.38 & 4.96 & 5.08 & 5.38 \\
\hline
\end{tabular}


Table 13. Mean values of biological yield/fed, seed yield/fed, straw yield/fed, seed protein yield/fed, seed $\mathrm{Zn}$ content and seed Mn content as affected by the interaction between foliar spray by some microelements and faba bean varieties during 2018/2019 $\left(1^{\text {st }}\right)$ and 2019/2020 $\left(2^{\text {nd }}\right)$ seasons.

\begin{tabular}{|c|c|c|c|c|c|c|c|c|c|c|c|c|c|}
\hline \multirow[t]{2}{*}{ Treatmen } & \multirow{2}{*}{$\begin{array}{c}\text { Trait } \\
\text { Season }\end{array}$} & \multicolumn{2}{|c|}{$\begin{array}{l}\text { Biological yield } \\
(\mathrm{kg} / \mathrm{fed})\end{array}$} & \multicolumn{2}{|c|}{$\begin{array}{c}\text { Seed yield } \\
(\mathrm{kg} / \mathrm{fed})\end{array}$} & \multicolumn{2}{|c|}{$\begin{array}{l}\text { Straw yield } \\
(\mathrm{kg} / \mathrm{fed})\end{array}$} & \multicolumn{2}{|c|}{$\begin{array}{l}\text { Seed protein } \\
\text { yield (kg/fed) }\end{array}$} & \multicolumn{2}{|c|}{$\begin{array}{c}\text { Seed Zn } \\
\text { content } \\
(\mathrm{mg} / \mathrm{kg})\end{array}$} & \multicolumn{2}{|c|}{$\begin{array}{c}\text { Seed Mn } \\
\text { content } \\
(\mathrm{mg} / \mathrm{kg}) \\
\end{array}$} \\
\hline & & $1^{\text {st }}$ & $2^{\text {nd }}$ & $1^{\text {st }}$ & $2^{\text {nd }}$ & $1^{\text {st }}$ & $2^{\text {nd }}$ & $1^{\text {st }}$ & $2^{\text {nd }}$ & $1^{\text {st }}$ & $2^{\text {nd }}$ & $1^{\text {st }}$ & $2^{\text {nd }}$ \\
\hline \multirow{3}{*}{ Control } & Giza 716 & 1005.4 & 1847.5 & 365.6 & 686.0 & 639.9 & 1161.6 & 76.85 & 149.69 & 91.22 & 99.77 & 19.77 & 24.73 \\
\hline & Nubaria 3 & 1273.5 & 2384.2 & 510.6 & 986.2 & 762.9 & 1398.0 & 97.26 & 197.65 & 92.61 & 101.59 & 19.93 & 25.82 \\
\hline & Sakha 4 & 1872.5 & 3050.2 & 723.3 & 1211.1 & 1149.2 & 1839.1 & 157.34 & 280.10 & 94.74 & 104.72 & 20.92 & 26.71 \\
\hline \multirow{3}{*}{ Zn } & Giza 716 & 1528.9 & 2538.1 & 590.4 & 1035.0 & 938.5 & 1503.0 & 134.27 & 247.52 & 111.54 & 118.85 & 22.13 & 27.70 \\
\hline & Nubaria 3 & 1964.7 & 3368.5 & 850.2 & 1552.5 & 1114.5 & 1816.0 & 177.25 & 328.43 & 111.87 & 122.44 & 23.00 & 29.62 \\
\hline & Sakha 4 & 2603.5 & 4175.0 & 1074.2 & 1822.3 & 1529.3 & 2352.6 & 252.31 & 448.99 & 115.63 & 125.64 & 24.37 & 30.43 \\
\hline \multirow{3}{*}{ Mn } & Giza 716 & 1346.1 & 2247.0 & 511.6 & 900.1 & 834.6 & 1346.9 & 112.41 & 204.61 & 94.53 & 103.50 & 33.53 & 39.20 \\
\hline & Nubaria 3 & 1815.1 & 3001.2 & 766.3 & 1362.4 & 1048.9 & 1638.8 & 153.87 & 276.44 & 96.27 & 105.64 & 35.49 & 41.49 \\
\hline & Sakha 4 & 2405.8 & 4064.3 & 981.0 & 1729.7 & 1424.9 & 2334.6 & 222.05 & 412.11 & 100.93 & 109.53 & 36.27 & 42.49 \\
\hline \multirow{3}{*}{$\begin{array}{c}\mathrm{Zn} \\
+ \\
\mathrm{MN}\end{array}$} & Giza 716 & 1619.0 & 2722.6 & 634.5 & 1124.1 & 984.5 & 1598.5 & 141.91 & 263.30 & 101.13 & 111.75 & 27.15 & 32.40 \\
\hline & Nubaria 3 & 2078.8 & 3524.9 & 921.4 & 1637.1 & 1157.4 & 1887.8 & 187.42 & 338.84 & 102.80 & 114.62 & 28.25 & 34.86 \\
\hline & Sakha 4 & 2704.8 & 4316.3 & 1137.7 & 1921.9 & 1567.1 & 2394.4 & 261.60 & 464.00 & 108.17 & 116.80 & 29.65 & 35.54 \\
\hline \multicolumn{2}{|c|}{ L.S.D at $5 \%$} & 250.8 & 291.8 & 143.2 & 150.8 & 139.6 & 163.4 & 12.70 & 15.66 & 8.36 & 9.30 & 6.78 & 8.02 \\
\hline
\end{tabular}

7- Effect of the interaction among phosphorus fertilization rates, microelements treatments and faba bean varieties:

Results in Table 14 revealed that the interaction among phosphorus fertilization rates $\times$ foliar spray by microelements treatments $\times$ faba bean varieties had significant effect on chlorophyll content index at 85 DAS, No. of seeds/plant, seed yield/plant, biological yield/fed, seed yield/fed and straw yield/fed in the both seasons.

Faba bean variety of Sakha 4 treated with 30 $\mathrm{P}_{2} \mathrm{O}_{5} /$ fed and mixed foliar application of $\mathrm{Zn}+\mathrm{Mn}$ gave the greatest No. of seeds/plant (39.12 and 67.57), seed yield/plant (31.28 and $60.52 \mathrm{~g})$, biological yield/fed (3037.4 and $4904.9 \mathrm{~kg})$, seed yield/fed (1307.6 and $2223.4 \mathrm{~kg}$ ) and straw yield/fed $(1729.8$ and $2681.5 \mathrm{~kg})$ in the both seasons, respectively. While, with the same faba bean variety and phosphorus fertilizer rate with foliar spray by singly Mn gave the highest chlorophyll content index at 85 DAS (42.24 and 46.54) in the both seasons, respectively. On the other hand, the minimum values in No. of seeds/plant (6.71 and 16.51), seed yield/plant (4.01 and $12.16 \mathrm{~g}$ ), biological yield/fed (643.3 and $16143.2 \mathrm{~kg}$ ), seed yield/fed (220.6 and $568.8 \mathrm{~kg}$ ) and straw yield/fed (422.7 and $1044.4 \mathrm{~kg}$ ) were recorded by faba bean variety of Giza 716 under without adding phosphorus or microelements in the both seasons, respectively. While, faba bean variety of Nubaria 3 under without applied phosphorus fertilization or microelements (tap water) produced the lowest chlorophyll content index at 85 DAS (25.41 and 28.21) in the both seasons, respectively.

\section{Conclusion}

This study recommends that Sakha 4 variety treated by $30 \mathrm{P}_{2} \mathrm{O}_{5} /$ fed and mixed spraying with $\mathrm{Zn}+$ $\mathrm{Mn}$ in order to improve the production of faba bean under the condition of Toukh Directorate, Kalyubia Governorate, Egypt. 
Table 14. Mean values of chlorophyll content index at 85 DAS, No. of seeds/plant, seed yield/plant, biological yield/fed, seed yield/fed and straw yield/fed as affected by the interaction between phosphorus fertilization rates, foliar spray by some microelements and faba bean varieties during 2018/2019 (1 $\left.1^{\text {st }}\right)$ and 2019/2020 (2 $\left.{ }^{\text {nd }}\right)$ seasons.

\begin{tabular}{|c|c|c|c|c|c|c|c|c|c|c|c|c|c|c|}
\hline \multicolumn{3}{|c|}{ Trait } & \multicolumn{2}{|c|}{$\begin{array}{c}\text { Chlorophyll } \\
\text { content index } \\
\text { at } 85 \text { DAS }\end{array}$} & \multicolumn{2}{|c|}{$\begin{array}{c}\text { No. of } \\
\text { seeds/plant }\end{array}$} & \multicolumn{2}{|c|}{$\begin{array}{c}\text { Seed } \\
\text { yield/plant (g) }\end{array}$} & \multicolumn{2}{|c|}{$\begin{array}{c}\text { Biological } \\
\text { yield (kg/fed) }\end{array}$} & \multicolumn{2}{|c|}{$\begin{array}{l}\text { Seed yield } \\
(\mathrm{kg} / \mathrm{fed})\end{array}$} & \multicolumn{2}{|c|}{$\begin{array}{l}\text { Straw yield } \\
\quad(\mathrm{kg} / \mathrm{fed})\end{array}$} \\
\hline $\mathbf{P}$ & M & V & $1^{\text {st }}$ & $2^{\text {nd }}$ & $1^{\text {st }}$ & $2^{\text {nd }}$ & $1^{\text {st }}$ & $2^{\text {nd }}$ & $1^{\text {st }}$ & $2^{\text {nd }}$ & $1^{\text {st }}$ & $2^{\text {nd }}$ & $1^{\text {st }}$ & $2^{\text {nd }}$ \\
\hline \multirow{12}{*}{0} & \multirow{3}{*}{ control } & Giza 716 & 27.25 & 29.58 & 6.71 & 16.51 & 4.01 & 12.16 & 643.3 & 1613.2 & 220.6 & 568.8 & 422.7 & 1044.4 \\
\hline & & Nubaria 3 & 25.41 & 28.21 & 9.78 & 19.81 & 7.01 & 16.99 & 1001.0 & 1847.8 & 385.6 & 734.5 & 615.4 & 1113.3 \\
\hline & & Sakha 4 & 30.66 & 33.37 & 15.31 & 30.36 & 10.09 & 22.73 & 1505.3 & 2559.8 & 555.0 & 950.2 & 950.3 & 1609.6 \\
\hline & \multirow{4}{*}{ Zn } & Giza 716 & 30.81 & 32.28 & 11.19 & 24.28 & 7.40 & 18.68 & 1113.5 & 2178.5 & 407.0 & 827.4 & 706.5 & 1351.1 \\
\hline & & Nubaria 3 & 26.89 & 31.41 & 15.71 & 29.35 & 12.40 & 26.26 & 1664.2 & 2731.7 & 682.0 & 1144.3 & 982.2 & 1587.4 \\
\hline & & Sakha 4 & 31.95 & 35.07 & 21.24 & 39.28 & 15.49 & 31.49 & 2185.2 & 3167.7 & 852.0 & 1332.0 & 1333.2 & 1835.7 \\
\hline & & Giza 716 & 33.21 & 36.43 & 9.80 & 22.47 & 6.37 & 16.98 & 972.8 & 1970.2 & 350.4 & 733.9 & 622.4 & 1236.3 \\
\hline & \multirow[t]{2}{*}{ Mn } & Nubaria 3 & 30.71 & 33.87 & 14.43 & 27.35 & 11.09 & 24.07 & 1530.0 & 2511.4 & 610.0 & 1023.9 & 920.0 & 1487.5 \\
\hline & & Sakha 4 & 36.42 & 40.47 & 20.12 & 38.09 & 14.34 & 29.97 & 2069.0 & 3003.8 & 788.7 & 1248.4 & 1280.3 & 1755.4 \\
\hline & \multirow{3}{*}{$\begin{array}{c}\mathrm{Zn} \\
+ \\
\mathbf{M N}\end{array}$} & Giza 716 & 32.35 & 34.04 & 12.27 & 26.27 & 8.26 & 20.39 & 1229.5 & 2389.2 & 454.3 & 921.5 & 775.2 & 1467.7 \\
\hline & & Nubaria 3 & 28.29 & 32.17 & 16.20 & 31.72 & 13.02 & 29.11 & 1735.2 & 2849.6 & 716.1 & 1201.1 & 1019.1 & 1648.5 \\
\hline & & Sakha 4 & 34.75 & 37.62 & 22.94 & 40.77 & 16.90 & 33.38 & 2245.6 & 3349.4 & 900.5 & 1435.9 & 1345.1 & 1913.5 \\
\hline \multirow{12}{*}{15} & \multirow{4}{*}{ control } & Giza 716 & 33.11 & 35.51 & 13.14 & 25.46 & 8.45 & 19.83 & 1155.3 & 1867.9 & 422.5 & 691.5 & 732.8 & 1176.4 \\
\hline & & Nubaria 3 & 27.59 & 32.35 & 14.36 & 30.34 & 10.80 & 27.35 & 1344.3 & 2587.9 & 540.0 & 1067.5 & 804.3 & 1520.4 \\
\hline & & Sakha 4 & 35.73 & 40.15 & 24.25 & 45.19 & 17.35 & 36.59 & 1987.3 & 3092.3 & 767.5 & 1229.5 & 1219.8 & 1862.8 \\
\hline & & Giza 716 & 34.36 & 37.46 & 18.94 & 35.39 & 13.37 & 29.37 & 1721.2 & 2558.7 & 668.5 & 1068.5 & 1052.7 & 1490.2 \\
\hline & \multirow[t]{3}{*}{ Zn } & Nubaria 3 & 30.31 & 34.14 & 23.88 & 43.62 & 20.32 & 41.50 & 2082.3 & 3542.7 & 916.0 & 1675.0 & 1166.3 & 1867.7 \\
\hline & & Sakha 4 & 38.09 & 42.64 & 32.65 & 56.44 & 24.81 & 49.00 & 2743.6 & 4459.2 & 1140.5 & 1950.0 & 1603.1 & 2509.2 \\
\hline & & Giza 716 & 36.25 & 40.08 & 16.64 & 32.49 & 11.50 & 26.57 & 1502.5 & 2271.3 & 575.0 & 928.5 & 927.5 & 1342.8 \\
\hline & \multirow[t]{2}{*}{ Mn } & Nubaria 3 & 31.29 & 35.46 & 20.78 & 40.25 & 17.24 & 37.93 & 1949.8 & 3182.7 & 832.0 & 1496.5 & 1117.8 & 1686.2 \\
\hline & & Sakha 4 & 40.81 & 44.07 & 29.26 & 52.50 & 21.56 & 44.51 & 2364.6 & 4358.9 & 978.0 & 1825.5 & 1386.6 & 2533.4 \\
\hline & \multirow{3}{*}{$\begin{array}{c}\text { Zn } \\
+ \\
\mathbf{M N}\end{array}$} & Giza 716 & 35.49 & 38.82 & 19.61 & 37.35 & 14.23 & 31.16 & 1754.1 & 2740.8 & 695.5 & 1158.0 & 1058.6 & 1582.8 \\
\hline & & Nubaria 3 & 31.11 & 34.78 & 24.55 & 45.62 & 21.13 & 44.06 & 2119.9 & 3804.6 & 956.5 & 1803.0 & 1163.4 & 2001.6 \\
\hline & & Sakha 4 & 39.42 & 43.37 & 33.79 & 59.69 & 26.50 & 52.13 & 2831.3 & 4694.7 & 1205.0 & 2106.5 & 1626.3 & 2588.2 \\
\hline \multirow{12}{*}{30} & \multirow{4}{*}{ control } & Giza 716 & 35.63 & 37.88 & 14.61 & 30.25 & 10.08 & 24.39 & 1217.7 & 2061.5 & 453.6 & 797.6 & 764.1 & 1263.9 \\
\hline & & Nubaria 3 & 30.41 & 35.68 & 16.33 & 37.78 & 13.47 & 34.59 & 1475.3 & 2716.9 & 606.2 & 1156.6 & 869.1 & 1560.3 \\
\hline & & Sakha 4 & 37.26 & 42.75 & 25.20 & 49.16 & 18.83 & 41.19 & 2124.9 & 3498.4 & 847.4 & 1453.6 & 1277.5 & 2044.8 \\
\hline & & Giza 716 & 35.98 & 40.26 & 21.39 & 42.47 & 15.46 & 35.76 & 1752.0 & 2877.0 & 695.7 & 1209.2 & 1056.3 & 1667.8 \\
\hline & \multirow[t]{3}{*}{ Zn } & Nubaria 3 & 30.73 & 36.45 & 24.74 & 47.31 & 21.17 & 45.29 & 2147.7 & 3831.0 & 952.7 & 1838.1 & 1195.0 & 1992.9 \\
\hline & & Sakha 4 & 38.79 & 43.59 & 38.33 & 61.38 & 29.56 & 54.00 & 2881.7 & 4898.0 & 1230.2 & 2185.0 & 1651.5 & 2713.0 \\
\hline & & Giza 716 & 37.81 & 42.53 & 19.08 & 38.16 & 13.54 & 31.95 & 1563.1 & 2499.5 & 609.3 & 1037.8 & 953.8 & 1461.7 \\
\hline & \multirow[t]{2}{*}{ Mn } & Nubaria 3 & 32.93 & 38.12 & 22.54 & 41.22 & 19.04 & 39.26 & 1965.6 & 3309.5 & 856.8 & 1566.7 & 1108.8 & 1742.8 \\
\hline & & Sakha 4 & 42.24 & 46.54 & 37.77 & 55.13 & 28.36 & 47.67 & 2783.9 & 4830.3 & 1176.2 & 2115.2 & 1607.7 & 2715.1 \\
\hline & \multirow{3}{*}{$\begin{array}{c}\text { Zn } \\
+ \\
\text { MN }\end{array}$} & Giza 716 & 36.41 & 41.05 & 23.89 & 43.86 & 17.86 & 37.62 & 1873.5 & 3037.8 & 753.7 & 1292.9 & 1119.8 & 1744.9 \\
\hline & & Nubaria 3 & 31.29 & 37.08 & 29.97 & 50.18 & 26.48 & 49.05 & 2381.3 & 3920.5 & 1091.6 & 1907.3 & 1289.7 & 2013.2 \\
\hline & & Sakha 4 & 40.65 & 44.81 & 39.12 & 67.57 & 31.28 & 60.52 & 3037.4 & 4904.9 & 1307.6 & 2223.4 & 1729.8 & 2681.5 \\
\hline & L.S.D a & $5 \%$ & 2.25 & 3.08 & 8.45 & 9.84 & 7.59 & 8.59 & 434.4 & 505.4 & 248.0 & 261.2 & 241.8 & 283.0 \\
\hline
\end{tabular}




\section{References}

A. O. A. C. (2005). Official Methods of Analysis of the Association of Official Analytical Chemists. Published by A.O.A.C. $16^{\text {th }}$ Ed., Washington, D.C., U. S. A.

Abd AlKader, E. Y.; S. Sh. El-Tabbakh; A. I. Nawar and H. M. Ibrahim (2017). Effect of phosphatic and potassium fertilization rates on some faba bean cultivars. J. Adv. Agric. Res. (Fac. Agric. Saba Basha), 22 (2): 188-207.

Al-Selawy, R. L. A.; A. H. Saudi and H. A. K. AlFarttoosi (2018). Effect of spry with concentrations of zinc on growth and yield of two broad bean (Vicia faba L.) cultivars. Univ. ThiQar J. agric. Res., 7 (1): 1-17.

Al-Shumary, A. M. J. (2020). The role of foliar zinc application on growth and yield of faba bean varieties. Int. J. Agric. Stat. Sci., 16 (1): $1157-$ 1161.

Barker, A.V. and D. J. Pilbeam (2006). Handbook of plant nutrition. Taylor \& Francis Group, Boca Raton London New York.

Bakhsh, A.; R. Khan; A. R. Gurmani; M. S. Khan; M. S. Nawaz and F. Haq; A. Farid (2008). Residual/direct of phosphorus application on wheat and rice yield under rice-wheat system. Gomal Univ. J. Res., 24, 29-35.

Desta, Y.; K. Habtegebrial and Y. Weldu (2015). Inoculation, phosphorous and zinc fertilization effects on nodulation, yield and nutrient uptake of Faba bean (Vicia faba L.) grown on calcaric cambisol of semiarid Ethiopia. J. Soil Sci. Environ. Manage., 6 (1): 9-15.

El-Agrodi, M. W.; A. M. El-Ghamry and H. H. Abdo (2017). Interactive effect of zinc and phosphorus on feba bean growth. J. Soil Sci. and Agric. Eng., Mansoura Univ., 8 (12): 661-667.

El-Shafey, A. I.; F. E. Waly; A. M. El-Garhy and M. M. H. Rahhal (2019). Effect of foliar spraying of some chelated microelements on growth, yield and chocolate spot disease severity of faba bean. Menoufia J. Plant Prod., 4 (3): 527550 .

El-Sobky, E. E. A. and M. A. T. Yasin (2017). Phosphorus and micronutrients fertilization impact on faba bean productivity (Vicia faba L.). Zagazig J. Agric. Res., 44 (3): 853-863.

Epstein, E. and A. J. Bloom (2005). Mineral nutrition of plants: principles and perspectives. $2^{\text {nd }}$ Edition. Sinauer Associates. Sunderland, MA.

Fageria, N. K. and F. M. P. Barbosa (2007). Dry matter and grain yield, nutrient uptake, and phosphorus use efficiency of lowland rice as influenced by phosphorus fertilization. Comm. Soil Sci. Plant Anal., 38:1289-1297.

Freed, R. D. (1991). MSTATC Microcomputer Statistical Program. Michigan State University, East Lansing, Michigan, USA.

Ghazi, D. A. (2017). Maximizing efficiency of rock phosphate as a source of P-Fertilization for faba bean (Vicia faba L.) plant. J. Soil Sci. and Agric. Eng., Mansoura Univ., 8 (12): 741-747.

Gomez, K. A. and A. A. Gomez (1984). Statistical procedures for agricultural research. $2^{\text {nd }}$, (ed). John Wiley and Sons, NY, U.S.A.

Jarecki, W.; J. Buczek and D. Bobrecka-Jamro (2016). Effect of foliar fertilization on the chlorophyll content in leaves and the chemical composition of faba bean seeds (Vicia faba L. (Partim)). J. Elem., 21 (4): 1305-1313.

Kabata, P.A. and H. Pendias (1999). Biogeochemistry of Trace Elements. PWN, Warsaw, Poland.

Kandil, A. A.; A. E. Sharief and A. S. A. Mahmoud (2019). Influence of phosphorus fertilization levels on productivity of some broad bean cultivars. Int. J. Adv. Res. Biol. Sci., 6 (7): 124-131.

Mahdy, A. Y. and H. A. Ahmed (2018). Effect of sowing dates and foliar application with zinc on production and quality of two faba bean (Vicia faba, L.) varieties. Alex. J. Agric. Sci., 63 (3): 129-139.

Mekkei, M. E. R. (2014). Effect of micronutrients foliar application on productivity and quality of some faba bean cultivars (Vicia faba L.). J. Plant Prod. Mansoura Univ., 5 (8): 1391-1401.

Nebiyu, A.; J. Diels and P. Boeckx (2016). Phosphorus use efficiency of improved faba bean (Vicia faba) varieties in low-input agroecosystems. J. Plant Nutr. Soil Sci., 179: 347354.

Negasa, G.; B. Bedadi and T. Abera (2019). Influence of phosphorus fertilizer rates on yield and yield components of faba bean (Vicia faba L.) varieties in Lemu Bilbilo District of Arsi Zone, Southeastern Ethiopia. Int. J. Plant \& Soil Sci., 28 (3): 1-11.

Nour El-Din, A. A.; M. M. Ibrahim; S. H. M. Abdel-Haleem and M. A. A. El-Said (2020). Effect of bio-fertilization and foliar spraying with some micro-elements on growth and productivity of two faba bean cultivars. J. Plant Prod., Mansoura Univ., 11 (2): 159-166.

Salem, A. K.; E. H. El-Harty; M. H. Ammar and S. S. Alghamdi (2014). Evaluation of faba bean (Vicia faba L.) performance under various micronutrient foliar applications and plant spacing. Life Sci. J., 11 (10): 1298-1304.

Weldua, Y.; M. Haileb and K. Habtegebrielb (2012). Effect of zinc and phosphorus fertilizers application on yield and yield components of faba bean (Vicia faba L.) grown in calcaric cambisol of semi-arid northern Ethiopia. J. Soil Sci. Environ. Manage., 3 (12): 320-326.

Yasmin, W.; S. K. Paul and M. P. Anwar (2020). Growth, yield and quality of faba bean (Vicia faba L.) in response to sowing date and phosphorus fertilization. Arch. Agric. Environ. Sci., 5 (1): 11 17. 
أداء بعض أصناف الفول البلاي وعلاقتهم بالتسميد الفوسفاتي والرش ببعض العناصر الصغرى

أماني عبد الوهاب إبراهيم الصافي ـ صلاح عباس حسن علام ـ السعيد محد محمود الجدوي ـ فاضل ضلبة زينهم الثيخ

قسم المحاصيل ـ كلية الزراعة ـ جامعة بنها ـ مصر.

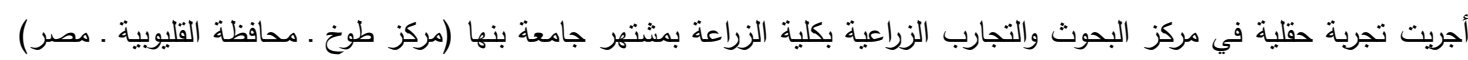

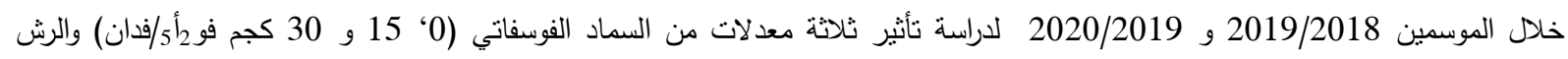
بأربعة معاملات من العناصر الصنري (بدون إضافة، الزنكك، المنجنيز والزنك + المنجنيز) على صفات النمو الخضري والمحصول ومكوناته

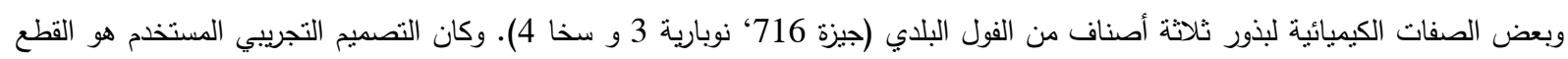

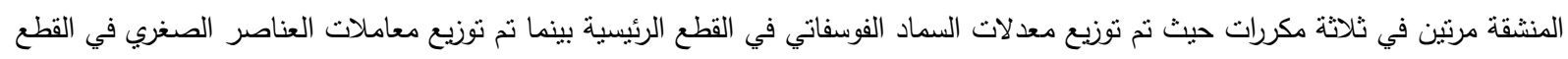
الثقية الأولى وتم توزيع الأصناف في القطع الثقية الثانية. ويمكن تلخيص أهم النتائج فيما يلي:.

أنشارت الننائج أن زيادة معدلات السماد الفوسفاني من 0 و 15 إلى 30 كجم فو أم//فدان حققت زيادة معنوية في معظم قيم صفات النمو

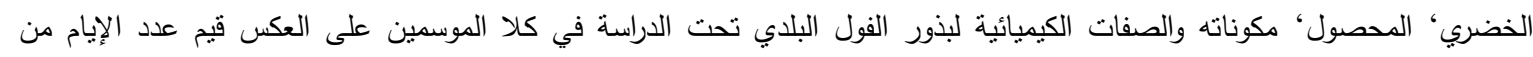

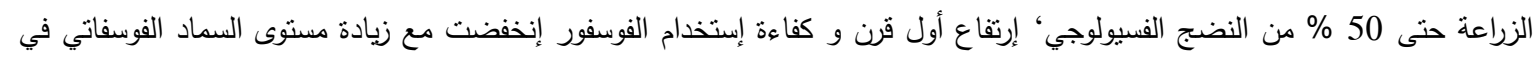

كلا الموسمين.

أوضحت الننائج أن الرش الخضري بالعناصر الصغرى بالمعاملة الفردية أو المعاملة المختلطة أدت إلى زيادة معنوية في قيم معظم صفات

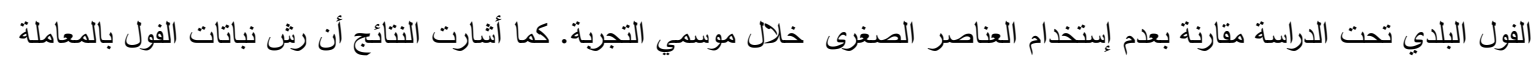
المختلطة (الزنك + المنجنيز) كانت أفضل المعاملات حيث أعطت أعلى القيم في معظم قيم صفات النمو الخضري، المحصول، مكوناته والصفات الكيميائية لبذور الفول البلدي في كلا الموسمين. أظهرت الننائج أن إداء أصناف الفول البلاي تحت الدراسة كانت مختلفة معنوية في معظم قيم الصفات الددروسة لمحصول الفول البلادي

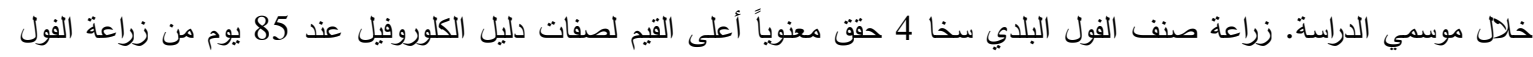

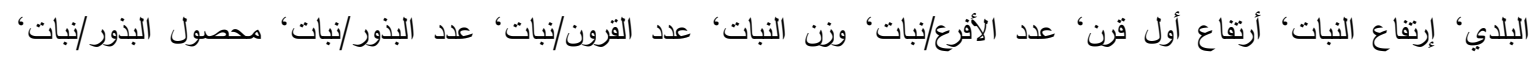

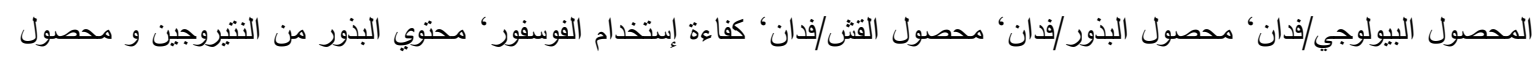

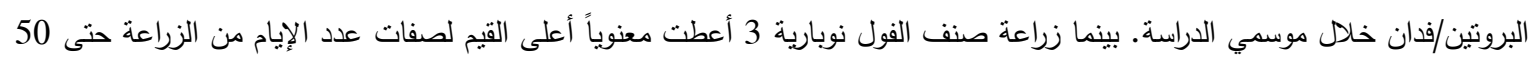

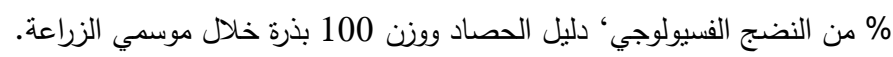

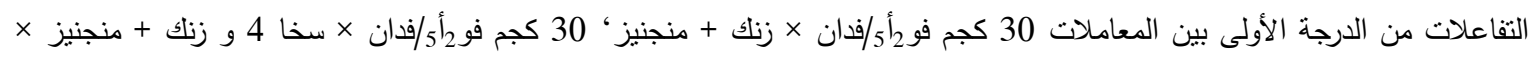

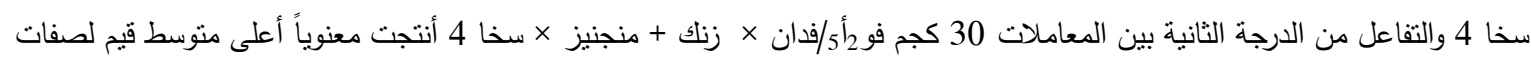

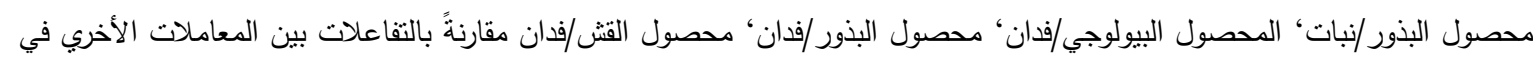

كلا الموسمين.

توصي الننائج بزراعة الفول البلاي صنف سخا 4 مع التسميد الفوسفاتي بمعدل 30 كجم فوأ5/فدان مع الرش الخضري بخليط من العناصر الصغرى (زنك 0.3 \% + منجنيز 0.3 \%) حيث عظت إنتاجية محصول الفول البلدي بوحدة المساحة في مركز طوخ ـ محافظة القليوبة . 